\title{
Genetic Inhibition of Serum Glucocorticoid Kinase 1 Prevents Obesity-related Atrial Fibrillation
}

Aneesh Bapat $\mathrm{MD}^{1}$, Guoping Li PhD${ }^{1}$, Ling Xiao PhD ${ }^{1}$, Maarten Hulsmans $\mathrm{PhD}^{2,3}$, Maximillian J Schloss $\mathrm{MD}^{2,3}$, Yoshiko Iwamoto $\mathrm{BSc}^{2,3}$, Justin Tedeschi BA ${ }^{1}$, Xinyu Yang ${ }^{5}$, Matthias Nahrendorf MD PhD ${ }^{2-4}$, Anthony Rosenzweig $\mathrm{MD}^{1}$, Patrick Ellinor MD PhD ${ }^{1}$, Saumya Das, MD PhD*1, David Milan, MD*1,6

1. Cardiovascular Research Center, Massachusetts General Hospital, Harvard Medical School, Boston, MA, USA.

2. Center for Systems Biology, Massachusetts General Hospital Research Institute and Harvard Medical School, Boston, MA, USA.

3. Department of Radiology, Massachusetts General Hospital, Boston, MA, USA.

4. Department of Internal Medicine I, University Hospital Wuerzburg, Wuerzburg, Germany.

5. Fangshan Hospital of Beijing, University of Traditional Chinese Medicine, Beijing, China

6. Leducq Foundation, Boston, MA, USA

- $\quad$ SD and DM contributed equally to this manuscript and share authorship.

Word Count: 8712

\section{Corresponding Author:}

David Milan, MD

265 Franklin St Ste 1902

Boston, MA 02110

E:dmilan@leducq.com 


\section{ABSTRACT:}

Rationale: Given its rising prevalence in both the adult and pediatric populations, obesity has become an increasingly important risk factor in the development of atrial fibrillation. However, a better mechanistic understanding of obesity-related atrial fibrillation is required. Serum glucocorticoid kinase 1 (SGK1) is a kinase positioned downstream of multiple obesity-related pathways, and prior work has shown a pathologic role for SGK1 signaling in ventricular remodeling and arrhythmias.

Objective: To determine the mechanistic basis of obesity associated atrial fibrillation and explore the therapeutic potential of targeting SGK1 in this context.

Methods and Results: We utilized a mouse model of diet induced obesity to determine the atrial electrophysiologic effects of obesity using electrophysiologic studies, optical mapping, and biochemical analyses. In C57BL/6J mice fed a high fat diet, there was upregulation of SGK1 signaling along with an increase in AF inducibility determined at electrophysiology (EP) study. These changes were associated with an increase in fibrotic and inflammatory signaling. Transgenic mice expressing a cardiac specific dominant negative SGK1 (SGK1 DN) were protected from obesity-related AF as well as the fibrotic and inflammatory consequences of AF. Finally, optical mapping demonstrated a shorter action potential duration and patch clamp revealed effects on $I_{N a}$, with a decreased peak current as well as a depolarizing shift in activation/inactivation properties in atrial myocytes.

Conclusions: Diet induced obesity leads to increased cardiac SGK1 signaling as well as an increase in AF inducibility in obese mice. Genetic SGK1 inhibition reduced AF inducibility, and this effect may be mediated by effects on inflammation, fibrosis, and cellular electrophysiology. 


\section{INTRODUCTION}

The rate of obesity in the US has risen steadily since 1960, and reached a prevalence of $42 \%$ in $2017-2018 .{ }^{1}$ With a pediatric obesity prevalence of $19 \%$ in $2017-2018,{ }^{2}$ there are no signs of slowing down. Atrial fibrillation (AF) is a common cardiac arrhythmia that affects about 5 million Americans and is associated with significant morbidity and mortality. ${ }^{3}$ Although many risk factors have been identified for AF, obesity has come to the forefront as a prominent- but potentially modifiable- one. Epidemiological studies demonstrate that nearly 1 in 5 cases of AF can be attributed to being overweight or obese. ${ }^{4}$ Importantly, data from the Women's Health Study showed that obese individuals who lost weight to $\mathrm{BMl}<30 \mathrm{~kg} / \mathrm{m}^{2}$ over a 5 year follow up period were found to have a reduced AF risk when compared to their persistently obese counterparts. ${ }^{5}$ Thus, not only is obesity a strong AF risk factor, but it may be one that is reversible.

The mechanistic relationship between obesity and AF is not completely delineated, and thus no specific therapies exist. However, a plethora of inciting factors have been proposed, and include alterations in hemodynamics, neurohormonal axis, inflammation, metabolism, and adipokines. ${ }^{6}$ Animal models of prolonged high fat diet feeding suggest a role for electroanatomic remodeling, ${ }^{7-10}$ inflammation, ${ }^{11}$ and decreased connexin expression. ${ }^{12}$ In addition, obesity is associated with activation of the NLRP3 inflammasome, ${ }^{13}$ which can be manipulated in cardiomyocytes to produce an atrial substrate susceptible to AF. ${ }^{14}$ 
Serum glucocorticoid kinase 1 (SGK1) is a PI3-kinase-dependent kinase, with structure similar to AKT. ${ }^{15}$ SGK1 expression and activation lies downstream of both insulin signaling pathways and mineralocorticoid receptor activation ${ }^{16}$ - both of which are associated with human AF. ${ }^{17-24}$ Additionally, systemic upregulation of both upstream pathways have been noted in multiple models of diet induced obesity, ${ }^{25-28}$ positioning SGK1 as a potential key mediator of AF pathogenesis in the context of obesity. Initial studies of SGK1 demonstrated that the signaling pathway can be activated in the heart by transverse aortic constriction, where acute activation promotes cardiomyocyte survival. ${ }^{29}$ However, SGK1 was subsequently shown to be activated in human heart failure, pointing to its role in maladaptive cardiac remodeling. Cardiac specific expression of constitutively active SGK1 in mice was associated with worsened TAC-induced cardiac dysfunction, adverse electrical remodeling and lethal ventricular arrhythmias, while genetic inhibition was protective. ${ }^{30}$ SGK1 signaling has also been implicated in murine cardiac inflammation $^{31}$ and NLRP3 inflammasome activation ${ }^{32}$ resulting from angiotensin II infusion induced hypertension. SGK1 signaling activates multiple pathways that overlap with the changes seen with obesity and metabolic syndrome, and hence presents an attractive potential therapeutic target.

We hypothesized that genetic inhibition of SGK1 would be protective in obesity-related AF through attenuation of obesity-related atrial electroanatomic remodeling and inflammation.

\section{METHODS}

\section{Animal Studies}


All studies were approved by the Institutional Animal Care and Use Committee (IACUC) and were in accordance with the NIH Guide for the Care and Use of Laboratory Animals. SGK1 dominant negative (DN) and constitutively active (CA) mice were generated as previously described, with cardiac-specific expression of a constitutively active (S422D) or dominant negative (K127M) SGK1 transgene driven by the $\alpha$-myosin heavy chain promotor. ${ }^{30}$ Cardiac specificity was confirmed by immunoblotting for an incorporated hemagglutinin (HA) epitope tag. (Supplemental Figure 1A) Transgene carrying mice were bred with wild type C57BL/6J mice to generate litters of transgenic and WT mice. Mice were genotyped by PCR for the presence of the transgene using tail DNA and the following primers: forward 5'-GGTAGCAATCCTCATCGCTTTC-3', reverse 5'CTTCAGGGTGTTTGCATGCA-3'. (Supplemental Figure 1B) Starting at 6 weeks of age, the SGK1 DN and WT littermates were fed a high fat diet (Research Diets D12492, 60\% fat by calories) for at least 10 weeks and up to 14 weeks until body weight was at least $34 \mathrm{~g}$. The weight cut-off was approximately the $95^{\text {th }}$ weight percentile among mice fed a control diet, and was used to exclude mice that may be resistant to diet induced obesity. ${ }^{33}$ Lean WT mice and SGK1 constitutively active mice were fed a control diet. Electrophysiology (EP) studies were performed under general anesthesia and terminated with extraction of the heart. Optical mapping and biochemical analyses required heart extraction, which was performed under deep anesthesia.

\section{Transthoracic Echocardiography}

Transthoracic echocardiograms were performed in unanesthetized mice using a GE Healthcare Vivid E90 system equipped with a $15 \mathrm{MHz}$ linear probe (L8-18i-D). Left ventricular function and dimensions were determined using M-mode in a parasternal short axis view at the level of the 
papillary muscles. Left ventricular end diastolic diameter (LVEDD) and left ventricular end systolic diameter (LVESD) were measured at maximal and minimal diameters and fractional shortening calculated as the change in LV internal dimensions between end diastole and end systole normalized to the end-diastolic dimension [(LVEDD-LVESD)/LVEDD]. Left atrial size was measured as an anteroposterior dimension in a 2D parasternal long axis view. Gain was optimized to delineate the endocardial surfaces and measurements were made using the GE Healthcare EchoPAC workstation platform.

\section{Tail-Cuff Blood Pressure}

Systolic, diastolic, and mean arterial pressures (SBP, DBP, MAP) were measured using a validated tail-cuff method that relies on volume pressure recording technology (Kent Scientific Corporation). Blood pressure measurements were made by using ten acclimation cycles followed by fifteen measurement cycles; the latter were averaged.

\section{Electrophysiology Studies}

EP studies were performed under general anesthesia induced by administering $5 \%$ isoflurane driven by an oxygen source into an induction chamber. Anesthesia was subsequently maintained with $1 \%-2 \%$ isoflurane in $95 \% \mathrm{O}_{2}$. An octapolar catheter (EPR-800, Millar) was inserted into the right jugular vein and positioned in the right atrium and ventricle. Sinus node function was determined by measuring the sinus node recovery time (SNRT) following 30 seconds of pacing at three cycle lengths $(120,100$ and $80 \mathrm{~ms})$. The Wenckebach cycle length was determined with progressively faster atrial pacing rates. Atrial, ventricular, and AV nodal refractory periods were 
measured using programmed electrical stimulation with overdrive pacing trains at 100ms followed by single extra-stimuli. Retrograde (VA) conduction Wenckebach cycle length was measured by pacing at progressively faster ventricular pacing rates. Provocative testing for arrhythmia induction was performed with triple extra-stimuli (S1-S2-S3) as well as rapid pacing at gradually faster rates to a pacing cycle length of $10 \mathrm{~ms}$. Atrial fibrillation (AF) was defined as a rapid atrial rhythm with atrial rate greater than ventricular rate and irregular ventricular response ( $R-R$ intervals). The duration of AF was measured from the end of the pacing train to the end of the rapid atrial activity. Mice were considered inducible for AF if they had episodes $>1 \mathrm{~s}$ in duration.

\section{Optical Mapping}

Isolation and perfusion of the heart was performed as previously described. ${ }^{34,35}$ Briefly, the mouse was anaesthetized using isoflurane, the heart excised, and perfused via an aortic cannula. The cannulated heart was perfused with a modified Tyrode solution $(128.2 \mathrm{mM} \mathrm{NaCl}$, 4.7 mM KCl, $1.19 \mathrm{mM} \mathrm{NaH}_{2} \mathrm{PO} 4,1.05 \mathrm{mM} \mathrm{MgCl}_{2}, 1.3 \mathrm{mM} \mathrm{CaCl}_{2}, 20.0 \mathrm{mM} \mathrm{NaHCO}_{3}, 11.1 \mathrm{mM}$ glucose; $\mathrm{pH} 7.35 \pm 0.05)$ using a Langendorff perfusion setup. Blebbistatin (10 mM, Tocris Bioscience) was used to arrest cardiac motion. The heart was stained for $30 \mathrm{~min}$ with a voltage sensitive dye (di-4-ANEPPs, $2 \mathrm{mmol} / \mathrm{L}$ in Dimethyl sulfoxide). Custom-made epicardial platinum electrodes and a Medtronic stimulator were used to pace the heart. Pacing was performed at 60-120ms cycle lengths at twice the capture threshold (4 ms square wave stimuli). A halogen light source (X-Cite $150 \mathrm{~W}$, filtered at $520+45 \mathrm{~nm}$ ) was used to excite fluorescence. Emissions $>610 \mathrm{~nm}$ were collected and focused onto an $80 \times 80$ CCD camera (RedShirt Imaging SMQ 
Camera and Macroscope IIA) using a $50 \mathrm{~mm} \times 2.7$ lens (numerical aperture 0.4). Data sampling was performed at 2000 frames per second with a filter setting of $1 \mathrm{kHz}$. A specifically designed Matlab program was used to perform data analysis in order to generate conduction velocities and APD at 50, 70, and $90 \%$ repolarization.

\section{Cardiomyocyte Isolation}

Mice were anaesthetized as described above and intraperitoneally injected with 0.2 cc heparin. Hearts were then dissected and mounted on a Langendorff system (Radnoti) via aortic cannulation. Hearts were perfused with $\mathrm{Ca}^{2+}$-free normal Tyrode's solution containing $\mathrm{NaCl} 137$ $\mathrm{mM}, \mathrm{KCl} 4 \mathrm{mM}, \mathrm{MgCl}_{2}$ 1mM, HEPES $10 \mathrm{mM}, \mathrm{NaH}_{2} \mathrm{PO}_{4} 0.33 \mathrm{mM}$, taurine $5 \mathrm{mM}$ and dextrose 10 $\mathrm{mM}$ ( $\mathrm{pH} 7.4$ ), followed by the same perfusion buffer containing collagenase $\mathrm{D}$ and $\mathrm{B}$ (Roche) and protease XIV (Sigma) at $37^{\circ} \mathrm{C}$. After enzymatic digestion, LA appendage was dissected into Kraftbrühe (KB) buffer containing $\mathrm{KCl} 25$ mM, $\mathrm{KH}_{2} \mathrm{PO}_{4} 10 \mathrm{mM}$, dextrose $20 \mathrm{mM}$, DL-aspartic acid potassium salt $10 \mathrm{mM}$, bovine albumin $0.1 \%$, L-glutamic acid potassium salt $100 \mathrm{mM}, \mathrm{MgSO}_{4} 2$ $\mathrm{mM}$, taurine $20 \mathrm{mM}$, EGTA $0.5 \mathrm{mM}$, creatine $5 \mathrm{mM}$, HEPES $5 \mathrm{mM}(\mathrm{pH}$ 7.2). Single LA cardiomyocytes were dispersed by triturating the digested tissue and seeded on laminin-coated 8-mm coverslips. After 1-hour incubation at $37^{\circ} \mathrm{C}$ in $5 \% \mathrm{CO}_{2}$ incubator, cardiomyocytes were treated with a gradually increased $\mathrm{Ca}^{2+}$ concentration from $0.06 \mathrm{mM}$ to $1.2 \mathrm{mM}$ in normal Tyrode's solution at RT.

\section{Patch Clamping}


Sodium currents $\left(I_{N a}\right)$ were recorded by whole-cell patch-clamp techniques in isolated murine LA cardiomyocytes at RT. Borosilicate-glass electrodes with tip-resistances 1.5-3 $\mathrm{M} \Omega$ were filled with pipette solution. For $I_{N a}$ recordings, pipette solution contained $\mathrm{CsCl} 135 \mathrm{mM}, \mathrm{NaCl} 10 \mathrm{mM}, \mathrm{CaCl}_{2}$ $2 \mathrm{mM}$, EGTA 5 mM, HEPES $10 \mathrm{mM}$, MgATP $5 \mathrm{mM}$ (pH 7.2 with $\mathrm{CsOH})$; bath solution contained $\mathrm{NaCl} 50 \mathrm{mM}, \mathrm{CaCl}_{2} 1.8 \mathrm{mM}, \mathrm{MgCl} 21 \mathrm{mM}, \mathrm{CsCl} 110 \mathrm{mM}$, dextrose $10 \mathrm{mM}$, HEPES $10 \mathrm{mM}$, nifedipine $0.001 \mathrm{mM}(\mathrm{pH} 7.4$ with $\mathrm{CsOH})$. Currents were low-pass filtered at $5 \mathrm{kHz}$ with an Axopatch 200B amplifier and digitized at $10 \mathrm{kHz}$ with a Digidata $1440 \mathrm{~A}$ A/D converter. I Na $_{\text {was }}$ obtained with $50-\mathrm{ms}$ depolarizations (- $100 \mathrm{mV}$ to $+40 \mathrm{mV}$ ) from a holding potential of $-120 \mathrm{mV}$ at $0.1 \mathrm{~Hz}$. Data were recorded with Clampex 10.3 and analyzed with Clampfit 10.3 (Molecular Devices Inc.). Cell-capacitance and series resistance were compensated by $\sim 70 \%$. Leakage compensation was not used. Currents were normalized to cell capacitance.

\section{Flow Cytometry}

Mice were perfused through the left ventricle with $10 \mathrm{~mL}$ of ice-cold PBS. Hearts were excised and atrial tissue was micro-dissected using a dissection microscope. After harvest, tissues were minced into small pieces and subjected to enzymatic digestion with $450 \mathrm{U} / \mathrm{mL}$ collagenase I, 125 $\mathrm{U} / \mathrm{mL}$ collagenase $\mathrm{XI}, 60 \mathrm{U} / \mathrm{mL}$ DNase I and $60 \mathrm{U} / \mathrm{mL}$ hyaluronidase (all Sigma-Aldrich) for 40 minutes at $37^{\circ} \mathrm{C}$ under agitation. Tissues were then triturated, and cells were filtered through a 40- $\mu \mathrm{m}$ nylon mesh, washed, and centrifuged to obtain single-cell suspensions. For a myeloid cell staining on processed heart samples, isolated cells were stained at $4^{\circ} \mathrm{C}$ in FACS buffer (PBS supplemented with $0.5 \%$ BSA) with mouse hematopoietic lineage markers including PEconjugated anti-mouse antibodies directed against B220 (clone RA3-6B2, 1:600), CD49b (clone 
DX5, 1:1200), CD90.2 (clone 53-2.1, 1:3000), CD103 (clone 2E7, 1:600), Ly6G (clone 1A8, 1:600),

NK1.1 (clone PK136, 1:600), and Ter-119 (clone TER-119, 1:600). This was followed by a second staining for CD11b (clone M1/70, 1:600), CD45 (clone 30-F11, 1:600), F4/80 (clone BM8, 1:600) and Ly6C (clone HK1.4, 1:600). DAPI was used as a cell viability marker. Neutrophils were identified as CD45highCD11bhigh(B220/CD49b/CD90.2/CD103/NK1.1/Ter-119)lowLy6Ghigh and cardiac macrophages as CD45highCD11bhigh(B220/CD49b/CD90.2/CD103/Ly6G/NK1.1/Ter119)lowF4/80highLy6Clow/int. Antibodies were purchased from BioLegend and BD Biosciences. Data were acquired on an LSRII (BD Biosciences) and analyzed with FlowJo software.

\section{Quantitative PCR of RNA}

Tissue samples were snap frozen and then lysed using a Tissue Lyser (Qiagen) in TRIzol (Thermo Fisher) followed by RNA extraction. A total of 500ng of RNA was reverse transcribed using the High Capacity cDNA Reverse Transcription Kit (Thermo Fisher). Real-time PCR was conducted with SsoAdvance Universal SYBR Green (Bio-Rad) using a QuantStudio 6 Flex Real-Time PCR System (Thermo Fisher). Quantification of all target-gene expression was normalized to $\beta$-actin. Primers for genes of interest are presented in supplemental table 1.

\section{Immunoblotting}

Western blot analysis was performed on snap-frozen atrial tissue. Tissue samples were lysed using a Tissue Lyser (Qiagen) in protein lysis buffer supplemented with protease and phosphatase inhibitors (Boston BioProducts). Protein content was measured using a commercially available kit (DC Protein Assay, Bio-Rad). Equal amounts (15-25 $\mu \mathrm{g}$ ) were treated with Laemmli buffer and $\beta$ - 
mercaptoethanol and incubated at $100^{\circ} \mathrm{C}$ for 5 minutes. The lysate was then electrophoresed on a 4-20\% SHS-polyacrylamide resolving gel and transferred to a PVDF membrane. The membrane was incubated overnight at $4^{\circ} \mathrm{C}$ with relevant antibodies, and then hybridization was completed with secondary antibody for 2 hours at room temperature. Antibody signal detection was achieved by employing the Clarity Western ECL Substrate (BioRad \#1705061). Imaging and image quantification were done via BioRad Chemidoc Touch Imaging System and ImageLab, respectively.

\section{Histology and Fibrosis Quantification}

Mice hearts were dissected and perfused with PBS. Hearts were then embedded in Tissue-Tek O.C.T. compound (Sakura Finetek), snap-frozen in 2-methylbutane on dry ice and sectioned into $10 \mu \mathrm{m}$ slices using CryoJane Tape-Transfer System (Leica). Masson's trichrome stain for cardiac fibrosis was performed according to the manufacturer's instructions (Sigma). Quantification of fibrosis in the atria was performed using the BZX Analyzer software.

\section{Cytokine ELISAs}

Cardiac puncture was performed during heart extraction to collect plasma. Commercially available kits were utilized to determine levels of IL-6 and CRP (R\&D systems).

\section{Statistics}

All statistical analyses were conducted with GraphPad Prism software. Animal group sizes were as low as possible and were empirically chosen. Categorical variables with binary outcomes were 
compared with the Fisher exact test. For two group comparisons of continuous variables, twotailed unpaired or paired Student's t-test was used to determine statistical significance. If a normal distribution could not be assumed, statistical significance was evaluated using the twotailed Mann-Whitney test. $\mathrm{P}$ values $<0.05$ were used to denote significance.

\section{RESULTS}

\section{Diet induced obesity results in increased AF susceptibility and increased SGK1 signaling}

We used diet induced obesity to create a mouse model of obesity-related AF. C57BL/6J wild type

(WT) mice were fed a high fat diet (HFD) starting at 6 weeks of age. (Figure 1A) After 4 to 10 weeks of HFD, mice underwent terminal EP studies and tissues were harvested. Although none of the mice ( 0 out of 3 ) were inducible for AF greater than 1 second after 4 weeks of HFD (average weight $31 \pm 2.2$ grams), 6 out of 7 were inducible for AF after 10 weeks of HFD (average weight 42 \pm 3.1 grams). In comparison, among age-matched mice fed a control diet for 10 weeks (average weight $30 \pm 2.8$ grams), only 1 out of 8 was inducible for AF during EP studies. (Figure 1B) Given this stark phenotype at 10 weeks of HFD, we proceeded to use 10 weeks of HFD as a model for obesity-related AF.

In addition to EP studies, a separate group of WT mice were euthanized after 10 weeks HFD to harvest cardiac tissue and determine SGK1 activation. The tissue was used to extract and analyze protein and mRNA expression. HFD resulted in a significant increase in atrial SGK1 gene expression, with a similar trend in the ventricles. (Figure $1 C, E$ ) In addition, in both atrial and ventricular tissue, high fat diet feeding led to a significant increase in the ratio of phosphorylated 
to total SGK1 as determined by Western blotting. (Figure 1D, F) Overall, these data demonstrate that diet induced obesity results in increased AF inducibility and is associated with an increase in SGK1 transcription and activation.

\section{Genetic SGK1 inhibition alters atrial electrophysiology and prevents obesity-related AF}

In order to test whether SGK1 plays a role in obesity-induced AF we employed a previously described transgenic mouse model that overexpresses a dominant negative form of SGK1 in cardiomyocytes (SGK1 DN). ${ }^{30}$ After 10-14 weeks of high fat diet, 79\% of SGK1 DN (23 out of 29) and $73 \%$ of WT littermates (22 out of 30 ) achieved the minimum $34 \mathrm{~g}$ weight. Over the course of feeding, there were no differences in weight gain or the final weight between SGK1 DN and WT littermates. Two-dimensional transthoracic echocardiography (TTE) was performed and did not reveal any differences in LV systolic or diastolic dimensions, fractional shortening or left atrial size between SGK1 DN and WT mice. Tail cuff blood pressure measurements showed no difference in systolic, diastolic, or mean arterial pressure. (Supplemental Figure 2)

Terminal EP studies were performed to determine EP parameters with focus on AF inducibility. Parameters related to sinus node function, AV node function, and refractory periods in atria and ventricles are presented in Table 1. There were no significant differences between the two groups at baseline. Programmed electrical stimulation with up to 2 extra-stimuli and rapid pacing were performed in both the atria and ventricles. There was a marked difference in AF inducibility between the two groups (Figure 2). While all (7 out of 7) WT mice were inducible for AF, genetic inhibition of SGK1 was significantly protective in terms of AF inducibility (2 out of 8). This finding 
was further supported by the observation that during the entirety of the EPS, even short (>250ms) episodes of AF were induced less frequently, and there was a lower total AF burden in SGK1 DN compared to WT mice.

Optical mapping of right atrial and left atrial appendages was performed on SGK1 DN and WT mice fed HFD using a voltage sensitive dye. (Table 2) Overall, the action potential duration was generally shorter in the obese SGK1 DN as compared to the obese WT mice in both atrial chambers and met statistical significance at 90\% repolarization (APD90). (Figure 3A) Additionally, there was a trend towards a decreased left atrial dV/dt in the SGK1 DN mice (WT 34 $\pm 3.6 \% / \mathrm{ms}$; DN 31.4 $\pm 4.3 \% / m s ; p=0.07)$. There were no significant differences in conduction velocity (CV) between the two obese mouse genotypes. Interestingly, within the WT obese mice, there were significant inter-atrial differences in APD90, CV and dV/dt; SGK1 DN mice only had an analogous interatrial difference in CV. (Figure 3B) Overall these data suggest that SGK1 activity plays a role in defining atrial and interatrial electrophysiology.

We performed focused patch clamping on atrial myocytes to further investigate the differences in APD and dV/dt found in optical mapping. Prior work has demonstrated the effect of SGK1 activation on sodium current via alteration of channel biophysical properties, as well as trafficking and localization of Nav1.5, the pore forming subunit of the channel. ${ }^{30}$ In addition, adipokines such as leptin have been shown to increase the late sodium current in left atrial myocytes. ${ }^{36}$ We suspected that the protective electrophysiologic consequences of SGK1 genetic inhibition may result from its effects on the sodium current. Whole cell patch clamp revealed that SGK1 DN left 
atrial myocytes- as compared to WT left atrial myocytes- had a significantly lower peak $I_{\mathrm{Na}}$ as well as a depolarizing shift in the steady state activation/inactivation properties. (Figure 4A-C) These data are consistent with previously published data regarding the effect of SGK1 activation/inactivation on $I_{N a}$ in ventricular myocytes ${ }^{30}$ and may account for the trend toward reduced $\mathrm{dV} / \mathrm{dt}$ in the SGK DN mice.

\section{Genetic inhibition of SGK1 prevents obesity-induced cardiac remodeling}

SGK1 DN mouse ventricles are resistant to TAC-induced fibrosis, ${ }^{30}$ so we hypothesized that SGK1 inhibition may protect from obesity-induced structural remodeling. Although there were no significant differences in fibrosis as measured by Masson-Trichrome staining between the three groups (Figure 5A), we suspected that this may be an insensitive technique. Western blotting revealed a marked increase in TGF- $\beta$ protein expression in all obese - as compared to lean- mice, with no difference based on genotype. However, protein expression of connective tissue growth factor (CTGF) was reduced in SGK1 DN as compared to WT obese mouse atria. (Figure 5B) In addition, quantitative PCR demonstrated a general increase in fibrosis-related genes in WT obese as compared to WT lean mice, with these changes attenuated in SGK1 DN obese mice (Figure 5C). Activity - and ratio- of matrix metalloproteinases (MMP) and tissue inhibitors of matrix metalloproteinases (TIMP) is known to affect the maintenance and turnover of the extra-cellular matrix (ECM). ${ }^{37-39}$ High fat diet feeding was associated with a significantly increased expression of tissue inhibitor of metalloproteinase 1 (TIMP1) and plasminogen activator inhibitor 1 (PAI-1), both of which are associated with increased ECM turnover. However, the ratio of TIMP1/MMP2 was significantly increased in obese WT atria as compared to lean WT mouse atria, with this 
difference minimized in the obese SGK1 DN atria (Figure 5D). A similar trend was noted in the ratio of TIMP1/MMP9. Overall, these data demonstrate attenuation of obesity-related profibrotic signaling in SGK1 DN atria, consistent with the previously described finding of reduced ventricular fibrosis in the TAC model.

Multiple animal models have demonstrated the obesity related downregulation of cardiac connexin proteins. ${ }^{11,12}$ We confirmed these results in our study by determining the level of gene and protein expression. Quantitative PCR showed a decrease in atrial expression of both connexin 40 and 43 in obese as compared to lean mice, but the decrease was mitigated or reversed by SGK1 inhibition. These findings were extended to protein translation, as immunoblotting revealed obesity- related decrease in atrial protein expression of connexin 40 and 43 which were ameliorated with SGK1 inhibition. The data presented here suggest a protective effect of SGK1 inhibition in terms of pro-fibrotic signaling and cell-cell connectivity. (Figure 5E-F)

\section{Genetic inhibition of SGK1 prevents obesity- induced inflammation and stress signaling}

Inflammation is thought to be involved in obesity induced pathology (including fibrosis), ${ }^{40}$ and we suspected that SGK1 signaling may contribute to pro-inflammatory pathways in the heart. We therefore evaluated the effect of SGK1 inhibition on atrial inflammation caused by obesity with quantitative PCR of inflammatory genes in WT lean, WT obese, and SGK1 DN obese mice. The genes of interest were either cytokines known to be involved in obesity-related inflammation or those thought to lie downstream of either mineralocorticoid or SGK1 signaling. ${ }^{32,41-44}$ Once again, 
cardiomyocyte specific genetic inhibition of SGK1 minimized obesity induced increases in genes related to inflammation. (Figure 6A) Given that SGK1 inhibition is restricted to cardiomyocytes, it is not surprising that plasma levels of circulating cytokines such as IL-6 and CRP were not impacted. (Supplemental Figure 3)

Of note, there was a marked obesity-induced atrial IL-1 $1 \beta$ expression, which was abolished with genetic inhibition of SGK1 (Figure 6A). SGK1 activation has been shown to affect expression of chemokine ligand 2 (CCL2), which is involved in the recruitment of inflammatory cells such as macrophages. ${ }^{41}$ Although there was only a modest difference in the expression of the CCL2 gene between the WT and SGK1 DN mouse atria, we interrogated this pathway further with flow cytometry and determined that SGK1 genetic inhibition abrogated a trend towards an increased atrial macrophage content caused by obesity. (Figure 6B) Although one could presume sheer difference in quantity of inflammatory cells as the source of the increase in IL-1 $1 \beta$, we pursued this avenue further by investigating downstream pathways.

We studied two pathways that we suspected may have been inhibited with SGK1 inhibition: the NLRP3 inflammasome and NFKB signaling. The NLRP3 inflammasome has been implicated in various obesity-related pathologies, including $A F$, and has been shown to be inhibited by pharmacologic SGK1 inhibition. ${ }^{32}$ Additionally, SGK1 activity has been shown to provoke nuclear translocation and hence activation of nuclear factor $\mathrm{kB} \cdot{ }^{45-47}$ We assayed inflammasome activity with a fluorometric measurement of caspase activity, which was found to be significantly lower in atrial tissue of SGK1 DN mice compared to WT. (Figure 6C) NLRP3 protein and mRNA expression 
both showed a trend towards an increase with HFD feeding, and SGK1 inhibition resulted in a significant decrease compared to WT littermates; there were no differences in caspase-1 protein expression (Figure 6A,6D). To further assess the role of the NLRP3 inflammasome in obesityrelated AF, EP studies were performed in age-matched obese NLRP3 ${ }^{-/-}$mice which demonstrated an intermediate AF phenotype, with 4 out of 10 mice inducible for AF greater than one second in duration. (Table 1)

NLRP3 expression is closely linked to NFKB activation, which is mechanistically linked to SGK1

activation. ${ }^{48,49}$ Western blotting of the $\mathrm{p} 65$ subunit of NFKB revealed a significantly $(p<0.05)$ lower protein expression of both phosphorylated- and hence transactivated form $-50,51$ and total NFKB p65 in SGK1 DN mouse atria. Overall, these data suggest that the protective effect of SGK1 inhibition in IL-1 $\beta$ expression may be mediated in part, by its role in modulating the NLRP3 and NFkB pathways.

\section{Constitutive SGK1 Activation Is Not Sufficient to Increase AF Susceptibility}

To determine whether SGK1 overactivation on its own determines AF susceptibility, we performed EP studies on age matched lean SGK1 CA and WT mice. There were no differences in AF inducibility noted between the two groups. Interestingly, SGK1 CA mice demonstrated a significantly longer PR interval, and had a trend $(p=0.14)$ towards a longer Wenckebach cycle length than their WT counterparts; these data suggest an effect on AV node function. Otherwise, there were no significant differences in EP parameters between the two lean groups. 


\section{DISCUSSION}

Obesity is a reversible risk factor for AF, and the rate of obesity continues unabated at epidemic proportions. Prior work examining the link between obesity and AF has implicated fibrosis, connexin dysregulation, inflammation, and ion channel alterations in arrhythmogenesis. Here we demonstrate that diet induced obesity upregulates atrial SGK1 transcription and activation. SGK1 inhibition is associated with a reduction in AF inducibility in a mouse model of high fat diet induced obesity. This protective effect was associated with alterations in atrial electrophysiology as well as an attenuation in the obesity-related structural remodeling and inflammation. Overall, SGK1 inhibition prevents some of the pathologic effects of obesity, making it a necessary signaling pathway in this AF model.

While cardiac SGK1 activity may be protective in acute pressure overload, ${ }^{29}$ persistent activation during chronic pressure overload has been shown to maladaptive. ${ }^{30}$ SGK1 is transcriptionally upregulated by circulating factors including glucocorticoids, mineralocorticoids, and insulin. ${ }^{52}$ Given the latter, we suspected that obese mice, which are known to have glucose intolerance, ${ }^{53}$ may have increased SGK1 expression. We demonstrate here that in fact diet induced obesity does increase SGK1 expression in the heart. Although this is a novel finding in the heart, similar models of obesity have been shown to increase SGK1 expression in the aorta, ${ }^{25}$ adipose tissue, ${ }^{26}$ and in the hippocampus. ${ }^{27}$

Obesity has been implicated in the development of both the triggers and substrate that underlie cardiac arrhythmias. ${ }^{6}$ There is discordant data regarding the effect of obesity on the cardiac 
sodium current. ${ }^{36,54-57}$ A particularly relevant recent study of mice with diet-induced obesity, for example, demonstrated decreased expression of the sodium channel subunit Nav1.5 associated with a concordant decrease in $I_{\mathrm{Na}}$ as well as APD shortening and decreased $\mathrm{dV} / \mathrm{dt}_{\mathrm{max}}$ in obese- as compared to lean- mouse left atria. ${ }^{58}$ These data would seem to stand in contrast to our findings, wherein SGK inhibition in obese mice was associated with a decrease in $I_{N a}$ but also a protective effect in terms of AF inducibility. However, despite the apparent contradiction, the same mouse model had $25 \%$ reduction in AF burden when treated with flecainide, an $I_{N a}$ blocker. $^{59}$ In the context of available literature, our results suggest that $I_{N a}$ inhibition may be protective in obesityrelated $A F$, but this incompletely explains the benefit derived from SGK1 genetic inhibition.

There is substantial data suggesting a role for obesity-induced structural remodeling in the pathogenesis of atrial fibrillation. Proposed mechanisms include interstitial fibrosis, ${ }^{7,8,10}$ connexin dysregulation, ${ }^{11,12}$ and even fatty infiltration. ${ }^{7}$ SGK1 activity in particular is associated with a number of fibrosing conditions throughout the body, and may be stimulated by TGF- $\beta$ activity. ${ }^{60}$ Although the data presented here did not demonstrate macroscopic histology-detected fibrosis, we do demonstrate an increased expression of several pro-fibrotic factors, including CTGF and $\alpha-S M A$, which were mitigated by SGK1 genetic inhibition. These findings further substantiate a role for SGK1 signaling in obesity-related fibrosis. ${ }^{30}$ MMPs and TIMPs have generally antagonistic functions and work in concert to maintain the homeostatic balance of the extracellular matrix. ${ }^{37,38}$ The relative changes seen here with obesity- which mimic those seen in aged, frail mouse atria- ${ }^{39}$ may suggest a profibrotic transcriptional programming. The protective effects of SGK1 genetic inhibition are not entirely unexpected, as they somewhat replicate the effects of 
cardiomyocyte mineralocorticoid receptor knockout. ${ }^{61}$ The role of SGK1 signaling on cardiomyocyte connexin expression are not described in literature, but there is extensive data regarding the effects of fibrosis and inflammation on connexin expression, so this may simply be a more downstream finding.

SGK1 activation has been linked to inflammation via both the NLRP3 inflammasome as well as NF-KB signaling. With respect to the latter, SGK1 directly phosphorylates IKK $\alpha$, resulting in

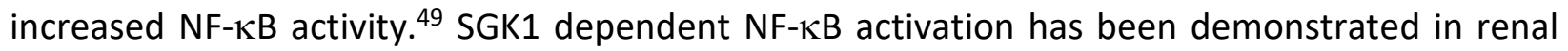
collecting ducts ${ }^{62}$ and aortic vascular smooth muscle cells. ${ }^{63}$ Recent literature has posited cardiomyocyte NLRP3 overexpression as a sufficient trigger for $\mathrm{AF},{ }^{14}$ and our data regarding atrial NLRP3 expression is compelling in this context. Prior studies have demonstrated an association between SGK1 and inflammasome activity, but the exact mechanism has not been clearly delineated. In a model of hypoxia-induced pulmonary arterial hypertension, SGK1 activity was shown to be associated with hypoxic pulmonary macrophage infiltration, whereby knockout of SGK1 reduced macrophage content. ${ }^{64}$ Meanwhile, a specific SGK1 inhibitor was shown to reduce NLRP3 inflammasome expression and mitigate angiotensin II induced cardiac inflammation and fibrosis. ${ }^{32}$ In our model, obesity resulted in a marked elevation in IL-1 $\beta$ - a cytokine frequently cited as pro-arrhythmic- which was prevented by SGK1 inhibition, perhaps through its effects on the NF-KB and NLRP3 axes.

An interesting aspect of this study to take note of - as in the Das et $a^{30}$ study regarding TACinduced cardiac remodeling- is that our model of SGK1 knockdown is restricted to 
cardiomyocytes via the $\alpha \mathrm{MHC}$ promoter. Yet, the effects seemingly extend to functions classically thought to be driven by non-cardiomyocytes; ECM maintenance is generally attributed to activated fibroblasts, and inflammation to monocytes. However, in vitro, cardiomyocytes have been shown to be capable of expressing fibrosis related transcripts, ${ }^{65}$ and even do so in response to leptin exposure. ${ }^{66}$ Murine in vivo models of cardiac fibrosis due to pressure overload have demonstrated an essential role for cardiomyocyte-dependent TGF- $\beta$ signaling. ${ }^{67}$ There is limited data regarding the role of cardiomyocyte derived signaling in inflammation, but cardiomyocyte

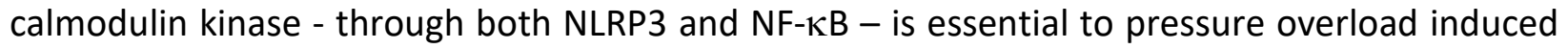
cardiac inflammation. ${ }^{68,69}$ A particularly relevant study from Rickard et al ${ }^{61}$ demonstrated cardiomyocyte mineralocorticoid receptors as essential in mineralocorticoid and salt induced cardiac fibrosis and inflammation. This is of critical interest in the context of our data, as the SGK1 axis lies downstream of mineralocorticoid receptor signaling via transcriptional regulation.

We acknowledge several limitations in our study. At first glance, it would seem that the stark differences in AF inducibility caused by SGK1 inhibition is incompletely explained by the less pronounced mechanistic differences. We propose that SGK1 inhibition- through its pleiotropic effects- decreases AF susceptibility via multiple contributory mechanisms. Another limitation innate to any rodent studies of AF is that a "positive" finding typically represents very brief (on the order of seconds) episodes of atrial tachyarrhythmia that are induced in vivo; i.e. these episodes are neither spontaneous nor sustained. We would propose that generally speaking mouse models of AF are models of the substrate, with the trigger provided by pacing/stimulation. 
In summary, this study suggests that pharmacologic inhibition of SGK1 should be further investigated for its therapeutic potential in obesity-related AF. In addition, this study, like others focused on obesity-related $A F$, describes a number of paths that may lead from obesity to AF beyond ion channel alterations. Notably, SGK1 activity seems to be required for many of these pro-arrhythmic pathways, suggesting a central role for this kinase in obesity-related AF, and thus making inhibition a potentially attractive target for intervention. Future work at targeting some of these paths may provide avenues to novel drug therapy for the increasingly prevalent obesityrelated $\mathrm{AF}$.

FUNDING SOURCES: Dr. Aneesh Bapat was supported by the NIH grant T32HL007604. Dr. Ling Xiao was supported by AHA 20CDA35260081. Dr. Saumya Das was funded by AHA SFRN SFRN35120123 and AHA 18IPA34170109. Dr. Matthias Nahrendorf was supported by NIH grant R35 HL139598. Dr. Maximillian J. Schloss was supported by Deutsche Forschungsgemeinschaft (SCHL 2221/1-1).

DISCLOSURES: SD, DM and AR are founding members of Long QT Therapeutics, which did not play any role in the funding or design of this study. M.N. has received funds or material research support from Alnylam, Biotronik, CSL Behring, GlycoMimetics, GSK, Medtronic, Novartis and Pfizer, as well as consulting fees from Biogen, Gimv, IFM Therapeutics, Molecular Imaging, Sigilon and Verseau Therapeutics. 


\section{REFERENCES}

1. Hales CM, Carroll MD, Fryar CD, Ogden CL. Prevalence of Obesity and Severe Obesity Among Adults: United States, 2017-2018. NCHS Data Brief. 2020;1-8.

2. Fryar CD, Carroll MD, Afful J. Prevalence of Overweight, Obesity, and Severe Obesity Among Children and Adolescents Aged 2-19 Years: United States, 1963-1965 Through 2017-2018. NCHS Heal E-Stats. 2020;1-7.

3. Morin DP, Bernard ML, Madias C, Rogers PA, Thihalolipavan S, Estes NAM. The State of the Art: Atrial Fibrillation Epidemiology, Prevention, and Treatment. Mayo Clin Proc [Internet]. 2016 [cited 2018 Feb 21];91:1778-1810. Available from:

http://linkinghub.elsevier.com/retrieve/pii/S0025619616305389

4. Huxley RR, Lopez FL, Folsom AR, Agarwal SK, Loehr LR, Soliman EZ, Maclehose R, Konety S, Alonso A. Absolute and Attributable Risks of Atrial Fibrillation in Relation to Optimal and Borderline Risk Factors: The Atherosclerosis Risk in Communities (ARIC) Study. Circulation [Internet]. 2011 [cited 2018 Feb 21];123:1501-1508. Available from: http://www.ncbi.nlm.nih.gov/pubmed/21444879

5. Tedrow UB, Conen D, Ridker PM, Cook NR, Koplan BA, Manson JE, Buring JE, Albert CM. The long- and short-term impact of elevated body mass index on the risk of new atrial fibrillation the WHS (women's health study). J Am Coll Cardiol [Internet]. 2010 [cited 2018 Feb 21];55:2319-27. Available from:

http://linkinghub.elsevier.com/retrieve/pii/S0735109710011010

6. Lavie CJ, Pandey A, Lau DH, Alpert MA, Sanders P. Obesity and Atrial Fibrillation Prevalence, Pathogenesis, and Prognosis. J Am Coll Cardiol [Internet]. 2017 [cited 2018 Feb 21];70:2022-2035. Available from: http://www.ncbi.nlm.nih.gov/pubmed/29025560

7. Mahajan R, Lau DH, Brooks AG, Shipp NJ, Manavis J, Wood JPM, Finnie JW, Samuel CS, Royce SG, Twomey DJ, Thanigaimani S, Kalman JM, Sanders P. Electrophysiological, Electroanatomical, and Structural Remodeling of the Atria as Consequences of Sustained Obesity. J Am Coll Cardiol [Internet]. 2015;66:1-11. Available from: http://www.ncbi.nlm.nih.gov/pubmed/26139051

8. Abed HS, Samuel CS, Lau DH, Kelly DJ, Royce SG, Alasady M, Mahajan R, Kuklik P, Zhang 
Y, Brooks AG, Nelson AJ, Worthley SG, Abhayaratna WP, Kalman JM, Wittert GA, Sanders P. Obesity results in progressive atrial structural and electrical remodeling: implications for atrial fibrillation. Hear Rhythm [Internet]. 2013;10:90-100. Available from: http://www.ncbi.nlm.nih.gov/pubmed/23063864

9. Zhang F, Hartnett S, Sample A, Schnack S, Li Y. High fat diet induced alterations of atrial electrical activities in mice. Am J Cardiovasc Dis [Internet]. 2016;6:1-9. Available from: http://www.ncbi.nlm.nih.gov/pubmed/27073731

10. Fukui A, Ikebe-Ebata Y, Kondo H, Saito S, Aoki K, Fukunaga N, Shinohara T, Masaki T, Teshima Y, Takahashi N. Hyperleptinemia Exacerbates High-Fat Diet-Mediated Atrial Fibrosis and Fibrillation. J Cardiovasc Electrophysiol [Internet]. 2017;28:702-710.

Available from: http://www.ncbi.nlm.nih.gov/pubmed/28257569

11. Takahashi K, Sasano T, Sugiyama K, Kurokawa J, Tamura N, Soejima Y, Sawabe M, Isobe M, Furukawa T. High-fat diet increases vulnerability to atrial arrhythmia by conduction disturbance via miR-27b. J Mol Cell Cardiol [Internet]. 2016;90:38-46. Available from: http://www.ncbi.nIm.nih.gov/pubmed/26654778

12. Meng T, Cheng G, Wei Y, Ma S, Jiang Y, Wu J, Zhou X, Sun C. Exposure to a chronic highfat diet promotes atrial structure and gap junction remodeling in rats. Int J Mol Med [Internet]. 2017;40:217-225. Available from:

http://www.ncbi.nlm.nih.gov/pubmed/28498436

13. Rheinheimer J, de Souza BM, Cardoso NS, Bauer AC, Crispim D. Current role of the NLRP3 inflammasome on obesity and insulin resistance: A systematic review. Metabolism [Internet]. 2017;74:1-9. Available from:

http://www.ncbi.nlm.nih.gov/pubmed/28764843

14. Yao C, Veleva T, Scott L, Cao S, Luge L, Chen G, Jeyabal P, Pan X, Alsina KM, Abu-Taha I, Ghezelbash S, Reynolds CL, Shen YH, LeMaire SA, Schmitz W, Müller FU, El-Armouche A, Eissa NT, Beeton C, Nattel S, Wehrens XHT, Dobrev D, Li N. Enhanced Cardiomyocyte NLRP3 Inflammasome Signaling Promotes Atrial Fibrillation. Circulation [Internet]. 2018;1. Available from: http://insights.ovid.com/crossref?an=00003017-90000000095079 
15. Park J, Leong ML, Buse P, Maiyar AC, Firestone GL, Hemmings BA. Serum and glucocorticoid-inducible kinase (SGK) is a target of the PI 3-kinase-stimulated signaling pathway. EMBO J [Internet]. 1999;18:3024-33. Available from:

http://www.ncbi.nlm.nih.gov/pubmed/10357815

16. Webster MK, Goya L, Ge Y, Maiyar AC, Firestone GL. Characterization of sgk, a novel member of the serine/threonine protein kinase gene family which is transcriptionally induced by glucocorticoids and serum. Mol Cell Biol [Internet]. 1993;13:2031-40. Available from: http://www.ncbi.nlm.nih.gov/pubmed/8455596

17. Neefs J, van den Berg NWE, Krul SPJ, Boekholdt SM, de Groot JR. Effect of Spironolactone on Atrial Fibrillation in Patients with Heart Failure with Preserved Ejection Fraction: PostHoc Analysis of the Randomized, Placebo-Controlled TOPCAT Trial. Am J Cardiovasc Drugs [Internet]. 2020;20:73-80. Available from: https://doi.org/10.1007/s40256-01900353-5

18. Tsai CT, Chiang FT, Tseng C Den, Hwang JJ, Kuo KT, Wu CK, Yu CC, Wang YC, Lai LP, Lin JL. Increased Expression of Mineralocorticoid Receptor in Human Atrial Fibrillation and a Cellular Model of Atrial Fibrillation. J Am Coll Cardiol. 2010;55:758-770.

19. Seccia TM, Caroccia B, Adler GK, Maiolino G, Cesari M, Rossi GP. Arterial Hypertension, Atrial Fibrillation, and Hyperaldosteronism: The Triple Trouble. Hypertension. 2017;69:545-550.

20. Swedberg K, Zannad F, McMurray JJV, Krum H, Van Veldhuisen DJ, Shi H, Vincent J, Pitt B. Eplerenone and atrial fibrillation in mild systolic heart failure: Results from the EMPHASIS-HF (Eplerenone in Mild Patients Hospitalization and Survlval Study in Heart Failure) study. J Am Coll Cardiol. 2012;59:1598-1603.

21. Takemoto Y, Ramirez RJ, Kaur K, Salvador-Montañés O, Ponce-Balbuena D, RamosMondragón R, Ennis SR, Guerrero-Serna G, Berenfeld O, Jalife J. Eplerenone Reduces Atrial Fibrillation Burden Without Preventing Atrial Electrical Remodeling. J Am Coll Cardiol. 2017;70:2893-2905.

22. Reil JC, Hohl M, Selejan S, Lipp P, Drautz F, Kazakow A, Münz BM, Müller P, Steendijk P, Reil GH, Allessie MA, Böhm M, Neuberger HR. Aldosterone promotes atrial fibrillation. 
Eur Heart J. 2012;33:2098-2108.

23. Liu T, Korantzopoulos P, Shao Q, Zhang Z, Letsas KP, Li G. Mineralocorticoid receptor antagonists and atrial fibrillation: A meta-analysis. Europace. 2016;18:672-678.

24. Maria Z, Campolo AR, Scherlag BJ, Ritchey JW, Lacombe VA. Dysregulation of insulinsensitive glucose transporters during insulin resistance-induced atrial fibrillation. Biochim Biophys Acta - Mol Basis Dis [Internet]. 2018;1864:987-996. Available from: https://linkinghub.elsevier.com/retrieve/pii/S0925443917304957

25. Scott TA, Babayeva O, Banerjee S, Zhong W, Francis SC. SGK1 is modulated by resistin in vascular smooth muscle cells and in the aorta following diet-induced obesity. Obesity. 2016;24:678-686.

26. Schernthaner-Reiter MH, Kiefer F, Zeyda M, Stulnig TM, Luger A, Vila G. Strong association of serum- and glucocorticoid-regulated kinase 1 with peripheral and adipose tissue inflammation in obesity. Int J Obes (Lond) [Internet]. 2015;39:1143-50. Available from: https://www.biorxiv.org/content/10.1101/2020.05.14.095471v3

27. Elahi M, Motoi Y, Shimonaka S, Ishida Y, Hioki H, Takanashi M, Ishiguro K, Imai Y, Hattori N. High-fat diet-induced activation of SGK1 promotes Alzheimer's disease-associated tau pathology. BioRxiv [preprint]. 2020;2507:1-9.

28. Wang C-Y, Liao JK. A mouse model of diet-induced obesity and insulin resistance. Methods Mol Biol [Internet]. 2012;821:421-33. Available from: http://www.ncbi.nlm.nih.gov/pubmed/22125082

29. Aoyama T, Matsui T, Novikov M, Park J, Hemmings B, Rosenzweig A. Serum and glucocorticoid-responsive kinase-1 regulates cardiomyocyte survival and hypertrophic response. Circulation [Internet]. 2005;111:1652-1659. Available from: http://www.ncbi.nlm.nih.gov/pubmed/15795328

30. Das S, Aiba T, Rosenberg M, Hessler K, Xiao C, Quintero PA, Ottaviano FG, Knight AC, Graham EL, Boström P, Morissette MR, del Monte F, Begley MJ, Cantley LC, Ellinor PT, Tomaselli GF, Rosenzweig A. Pathological role of serum- and glucocorticoid-regulated kinase 1 in adverse ventricular remodeling. Circulation [Internet]. 2012;126:2208-19. Available from: http://www.ncbi.nlm.nih.gov/pubmed/20402989 
31. Yang M, Zheng J, Miao Y, Wang Y, Cui W, Guo J, Qiu S, Han Y, Jia L, Li H, Cheng J, Du J. Serum-glucocorticoid regulated kinase 1 regulates alternatively activated macrophage polarization contributing to angiotensin II-induced inflammation and cardiac fibrosis. Arterioscler Thromb Vasc Biol [Internet]. 2012;32:1675-86. Available from: http://www.ncbi.nlm.nih.gov/pubmed/22556335

32. Gan W, Ren J, Li T, Lv S, Li C, Liu Z, Yang M. The SGK1 inhibitor EMD638683, prevents Angiotensin II-induced cardiac inflammation and fibrosis by blocking NLRP3 inflammasome activation. Biochim Biophys Acta - Mol Basis Dis [Internet]. 2018;1864:110. Available from: http://dx.doi.org/10.1016/j.bbadis.2017.10.001

33. Enriori PJ, Evans AE, Sinnayah P, Jobst EE, Tonelli-Lemos L, Billes SK, Glavas MM, Grayson BE, Perello M, Nillni EA, Grove KL, Cowley MA. Diet-Induced Obesity Causes Severe but Reversible Leptin Resistance in Arcuate Melanocortin Neurons. Cell Metab. 2007;5:181194.

34. Glukhov A V, Flagg TP, Fedorov V V, Efimov IR, Nichols CG. Differential K(ATP) channel pharmacology in intact mouse heart. J Mol Cell Cardiol [Internet]. 2010;48:152-60. Available from: http://www.ncbi.nlm.nih.gov/pubmed/19744493

35. Glukhov A V, Fedorov V V, Anderson ME, Mohler PJ, Efimov IR. Functional anatomy of the murine sinus node: high-resolution optical mapping of ankyrin-B heterozygous mice. Am J Physiol Heart Circ Physiol [Internet]. 2010;299:H482-91. Available from: http://www.ncbi.nlm.nih.gov/pubmed/20525877

36. Lin YKYJ, Chen YCYJ, Huang JH, Lin YKYJ, Huang SS, Chen SA, Chen YCYJ. Leptin modulates electrophysiological characteristics and isoproterenol-induced arrhythmogenesis in atrial myocytes. J Biomed Sci. 2013;20:1-9.

37. Spinale FG. Myocardial Matrix Remodeling and the Matrix Metalloproteinases: Influence on Cardiac Form and Function. Physiol Rev [Internet]. 2007;87:1285-1342. Available from: http://www.physiology.org/doi/10.1152/physrev.00012.2007

38. Kassiri Z, Khokha R. Myocardial extra-cellular matrix and its regulation by metalloproteinases and their inhibitors. Thromb Haemost [Internet]. 2005;93:212-9. Available from: http://www.ncbi.nlm.nih.gov/pubmed/15711735 
39. Jansen HJ, Moghtadaei M, Mackasey M, Rafferty SA, Bogachev O, Sapp JL, Howlett SE, Rose RA. Atrial structure, function and arrhythmogenesis in aged and frail mice. Sci Rep [Internet]. 2017;7:44336. Available from:

http://www.ncbi.nlm.nih.gov/pubmed/28290548

40. Harada M, Nattel S. Implications of Inflammation and Fibrosis in Atrial Fibrillation Pathophysiology. Card Electrophysiol Clin [Internet]. 2021;13:25-35. Available from: https://doi.org/10.1016/j.ccep.2020.11.002

41. Brem AS, Morris DJ, Gong R. Aldosterone-induced fibrosis in the kidney: questions and controversies. Am J Kidney Dis [Internet]. 2011;58:471-9. Available from:

http://www.ncbi.nlm.nih.gov/pubmed/21705125

42. Chen B, Wang P, Brem A, Dworkin L, Liu Z, Gong R. Mineralocorticoid receptor: A hidden culprit for hemodialysis vascular access dysfunction. EBioMedicine [Internet]. 2019;39:621-627. Available from: http://www.ncbi.nlm.nih.gov/pubmed/30527626

43. Mouton AJ, Li X, Hall ME, Hall JE. Obesity, hypertension, and cardiac dysfunction novel roles of immunometabolism in macrophage activation and inflammation. Circ Res. 2020;789-806.

44. Yao L, Herlea-Pana O, Heuser-Baker J, Chen Y, Barlic-Dicen J. Roles of the chemokine system in development of obesity, insulin resistance, and cardiovascular disease. $J$ Immunol Res. 2014;2014.

45. Vallon V, Wyatt AW, Klingel K, Huang DY, Hussain A, Berchtold S, Friedrich B, Grahammer F, BelAiba RS, Görlach A, Wulff P, Daut J, Dalton ND, Ross J, Flögel U, Schrader J, Osswald $H$, Kandolf R, Kuhl D, Lang F. SGK1-dependent cardiac CTGF formation and fibrosis following DOCA treatment. J Mol Med. 2006;84:396-404.

46. Belaiba RS, Djordjevic T, Bonello S, Artunc F, Lang F, Hess J, Görlach A. The serum- and glucocorticoid-inducible kinase Sgk-1 is involved in pulmonary vascular remodeling: Role in redox-sensitive regulation of tissue factor by thrombin. Circ Res. 2006;98:828-836.

47. Zhang L, Cui R, Cheng X, Du J. Antiapoptotic effect of serum and glucocorticoid-inducible protein kinase is mediated by novel mechanism activating ІкB kinase. Cancer Res. 2005;65:457-464. 
48. Bauernfeind FG, Horvath G, Stutz A, Alnemri ES, MacDonald K, Speert D, FernandesAlnemri T, Wu J, Monks BG, Fitzgerald KA, Hornung V, Latz E. Cutting Edge: NF-KB Activating Pattern Recognition and Cytokine Receptors License NLRP3 Inflammasome Activation by Regulating NLRP3 Expression. J Immunol [Internet]. 2009;183:787-791. Available from: http://www.jimmunol.org/lookup/doi/10.4049/jimmunol.0901363

49. Tai DJC, Su CC, Ma YL, Lee EHY. SGK1 phosphorylation of IKB kinase $\alpha$ and p300 upregulates NF-KB activity and increases N-methyl-D-aspartate receptorNR2A and NR2B expression. J Biol Chem. 2009;284:4073-4089.

50. Chen LF, Greene WC. Shaping the nuclear action of NF-KB. Nat Rev Mol Cell Biol. 2004;5:392-401.

51. Viatour P, Merville MP, Bours V, Chariot A. Phosphorylation of NF-kB and IкB proteins: Implications in cancer and inflammation. Trends Biochem Sci. 2005;30:43-52.

52. Lang F, Shumilina E. Regulation of ion channels by the serum- and glucocorticoidinducible kinase SGK1. FASEB J. 2013;27:3-12.

53. Schile AJ. Jaxpheno11: Early stages of type 2 diabetes in C57BL/6J male mice on a highfat diet [Internet]. Mouse Phenome Database Jackson Lab. 2017;Available from: https://phenome.jax.org/projects/Jaxpheno11

54. Lin YK, Chen YCYJ, Kao YH, Tsai CF, Yeh YH, Huang JL, Cheng CC, Chen SA, Chen YCYJ. A monounsaturated fatty acid (oleic acid) modulates electrical activity in atrial myocytes with calcium and sodium dysregulation. Int J Cardiol [Internet]. 2014;176:191-198. Available from: http://dx.doi.org/10.1016/j.ijcard.2014.07.004

55. Biet M, Morin N, Benrezzak O, Naimi F, Bellanger S, Baillargeon JP, Chouinard L, GalloPayet N, Carpentier AC, Dumaine R. Lasting alterations of the sodium current by shortterm hyperlipidemia as a mechanism for initiation of cardiac remodeling. Am J Physiol Hear Circ Physiol. 2014;306:291-297.

56. O’Connell RP, Musa H, Gomez MSM, Avula UM, Herron TJ, Kalifa J, Anumonwo JMB, Talkachova A. Free fatty acid effects on the atrial myocardium: Membrane ionic currents are remodeled by the disruption of T-tubular architecture. PLoS One. 2015;10:1-18.

57. Wu CC, Su MJ, Chi JF, Wu MH, Lee YT. Comparison of aging and hypercholesterolemic 
effects on the sodium inward currents in cardiac myocytes. Life Sci. 1997;61:1539-1551.

58. McCauley MD, Hong L, Sridhar A, Menon A, Perike S, Zhang M, Da Silva IB, Yan J, Bonini MG, Ai X, Rehman J, Darbar D. Ion Channel and Structural Remodeling in ObesityMediated Atrial Fibrillation. 2020.

59. Ornelas-Loredo A, Kany S, Abraham V, Alzahrani Z, Darbar FA, Sridhar A, Ahmed M, Alamar I, Menon A, Zhang M, Chen Y, Hong L, Konda S, Darbar D. Association between Obesity-Mediated Atrial Fibrillation and Therapy with Sodium Channel Blocker Antiarrhythmic Drugs. JAMA Cardiol. 2020;5:57-64.

60. Lang F, Böhmer C, Palmada M, Seebohm G, Strutz-Seebohm N, Vallon V. (Patho)physiological significance of the serum- and glucocorticoid- inducible kinase isoforms. Physiol Rev. 2006;86:1151-1178.

61. Rickard AJ, Morgan J, Bienvenu LA, Fletcher EK, Cranston GA, Shen JZ, Reichelt ME, Delbridge LM, Young MJ. Cardiomyocyte mineralocorticoid receptors are essential for deoxycorticosterone/salt-mediated inflammation and cardiac fibrosis. Hypertension. 2012;60:1443-1450.

62. Leroy V, De Seigneux S, Agassiz V, Hasler U, Rafestin-Oblin ME, Vinciguerra M, Martin PY, Féraille E. Aldosterone activates NF-KB in the collecting duct. J Am Soc Nephrol. 2009;20:131-144.

63. VoelkI J, Luong TTD, Tuffaha R, Musculus K, Auer T, Lian X, Daniel C, Zickler D, Boehme B, Sacherer M, Metzler B, Kuhl D, Gollasch M, Amann K, Müller DN, Pieske B, Lang F, Alesutan I. SGK1 induces vascular smooth muscle cell calcification through NF-?B signaling. J Clin Invest. 2018;128:3024-3040.

64. Xi X, Zhang J, Wang J, Chen Y, Zhang W, Zhang X, Du J, Zhu G. SGK1 Mediates Hypoxic Pulmonary Hypertension through Promoting Macrophage Infiltration and Activation. $2019 ; 2019$.

65. Heras-Bautista CO, Mikhael N, Lam J, Shinde V, Katsen-Globa A, Dieluweit S, Molcanyi M, Uvarov V, Jütten P, Sahito RGA, Mederos-Henry F, Piechot A, Brockmeier K, Hescheler J, Sachinidis A, Pfannkuche K. Cardiomyocytes facing fibrotic conditions re-express extracellular matrix transcripts. Acta Biomater. 2019;89:180-192. 
66. Schram K, De Girolamo S, Madani S, Munoz D, Thong F, Sweeney G. Leptin regulates MMP-2, TIMP-1 and collagen synthesis via p38 MAPK in HL-1 murine cardiomyocytes. Cell Mol Biol Lett. 2010;15:551-563.

67. Koitabashi N, Danner T, Zaiman AL, Pinto YM, Rowell J, Mankowski J, Zhang D, Nakamura T, Takimoto E, Kass DA. Pivotal role of cardiomyocyte TGF- $\beta$ signaling in the murine pathological response to sustained pressure overload. J Clin Invest. 2011;121:2301-2312.

68. Suetomi T, Willeford A, Brand CS, Cho Y, Ross RS, Miyamoto S, Brown JH, Jolla L, Brown JH, Jolla L, Miyamoto S. Inflammation and NLRP3 Inflammasome Activation Initiated in Response to Pressure Overload by CaMKII $\delta$ Signaling in Cardiomyocytes are Essential for Adverse Cardiac Remodeling. 2018;2530-2544.

69. Willeford A, Suetomi T, Nickle A, Hoffman HM, Miyamoto S, Heller Brown J. CaMKIIסmediated inflammatory gene expression and inflammasome activation in cardiomyocytes initiate inflammation and induce fibrosis. JCl insight. 2018;3. 


\section{TABLES:}

Table 1. Cardiac electrophysiological parameters determined with in vivo EP study in obese WT, SGK1 DN, and NLRP ${ }^{-/-}$mice

\begin{tabular}{ccc}
\hline WT & SGK1 DN \\
$(n=7)$ & $(n=8)$ & NLRP3 $^{-1-}$ \\
$(n=10)$
\end{tabular}

Basic EKG Parameters

$\begin{array}{lccc}\mathrm{BCL}(\mathrm{ms}) & 130 \pm 19 & 126 \pm 16 & 129 \pm 3 \\ \mathrm{PR}_{100 \mathrm{~ms}}(\mathrm{~ms}) & 47 \pm 8 & 45 \pm 7 & 52 \pm 7^{*} \\ \mathrm{QRS}_{100 \mathrm{~ms}}(\mathrm{~ms}) & 31 \pm 3 & 29 \pm 3 & 29 \pm 3\end{array}$

Sinus node function

$\mathrm{SNRT}_{80 \mathrm{~ms}}(\mathrm{~ms})$

$169 \pm 28$

$167 \pm 65$

$182 \pm 37$

AV node characteristics

Wenckebach

cycle length (ms)

$75 \pm 5$

$76 \pm 5$

$78 \pm 6$

Atrial characteristics

$\operatorname{AERP}_{100 \mathrm{~ms}}(\mathrm{~ms})$

$31 \pm 5$

$30 \pm 6$

$31 \pm 8$

Ventricular characteristics

$\operatorname{VERP}_{100 \mathrm{~ms}}(\mathrm{~ms})$

$30 \pm 5$

$32 \pm 7$

$27 \pm 3^{*}$

\section{Atrial Arrhythmias}

Inducibility (\%)

100

Burden (s)

$91 \pm 138$

Frequency (\#)

$6 \pm 5$
$25^{*}$

$1.5 \pm 3^{*}$

$1.6 \pm 3^{*}$
$40^{*}$

$8 \pm 17$

$4 \pm 5$

Data are mean $\pm S D$; asterisk $\left({ }^{*}\right)$ indicates $P<0.05$ compared to WT. Subscript denotes $P C L$ where appropriate. BCL, basic cycle length; PR100ms, PR interval duration; QRS $100 \mathrm{~ms}, \mathrm{QRS}$ duration; SNRT, sinus node recovery time; $A E R P_{100 \mathrm{~ms}}$, atrial effective refractory period; VERP ${ }_{100 \mathrm{~ms}}$, ventricular effective refractory period. 
Table 2. Optical mapping derived action potential durations, conduction velocity, and AP upstroke velocity in WT and SGK1 DN atria

\begin{tabular}{cccc}
\hline & WT & SGK1 DN & P value \\
\hline Right Atrium & $\mathbf{N}=15$ & $\mathbf{N}=19$ & \\
CV $(\mathrm{m} / \mathrm{s})$ & $0.67 \pm 0.26$ & $0.61 \pm 0.14$ & 0.42 \\
APD50 $(\mathrm{ms})$ & $11.1 \pm 1.2$ & $10.0 \pm 1.7$ & $\mathbf{0 . 0 4}$ \\
APD70 (ms) & $17.9 \pm 2$ & $16.1 \pm 2.6$ & $\mathbf{0 . 0 4}$ \\
APD90 (ms) & $22 \pm 2.7$ & $19.6 \pm 2.7$ & $\mathbf{0 . 0 3}$ \\
dV/dt (\%/ms) & $29 \pm 4.4$ & $30.5 \pm 5.3$ & 0.48 \\
Left Atrium & $\mathbf{N}=11$ & $\mathbf{N}=15$ & 0.68 \\
CV $(\mathrm{m} / \mathrm{s})$ & $0.78 \pm 0.31$ & $0.74 \pm 0.22$ & 0.41 \\
APD50 $(\mathrm{ms})$ & $9.4 \pm 1.3$ & $8.9 \pm 1.7$ & 0.21 \\
APD70 (ms) & $15.9 \pm 2.7$ & $14.6 \pm 2.6$ & $\mathbf{0 . 0 2}$ \\
APD90 (ms) & $20.9 \pm 2.5$ & $18.0 \pm 2.9$ & 0.07 \\
dV/dt $(\% / m s)$ & $34 \pm 3.6$ & $31.4 \pm 4.3$ &
\end{tabular}

Data are mean \pm SD; unpaired $t$ test. PCL $100 \mathrm{~ms}$ for all measurements. CV, conduction velocity; APD50, action potential duration at $50 \%$ repolarization; APD90, action potential duration at $90 \%$ repolarization; dV/dt, AP upstroke velocity from $20-80 \%$ depolarization calculated as percent per ms. 
Table 3. Cardiac electrophysiological parameters determined with in vivo EP study in lean WT and SGK1 CA mice

WT
$(n=3)$$\quad \begin{gathered}\text { SGK1 CA } \\ (n=5)\end{gathered}$

\section{Basic EKG Parameters}

$\begin{array}{lcc}\mathrm{BCL}(\mathrm{ms}) & 118 \pm 18 & 118 \pm 8 \\ \mathrm{PR}_{100 \mathrm{~ms}}(\mathrm{~ms}) & 40 \pm 5 & 52 \pm 6^{*} \\ \mathrm{QRS}_{100 \mathrm{~ms}}(\mathrm{~ms}) & 28 \pm 3 & 29 \pm 2\end{array}$

\section{Sinus node function}

$\mathrm{SNRT}_{80 \mathrm{~ms}}$ (ms)

$135 \pm 10$

$162 \pm 20$

\section{AV node characteristics}

Wenckebach cycle

length (ms)

AVERP

$43 \pm 4$

$47 \pm 8$

\section{Atrial characteristics}
$\operatorname{AERP}_{100 \mathrm{~ms}}(\mathrm{~ms})$
$24 \pm 7$
$28 \pm 6$

Ventricular characteristics

$\operatorname{VERP}_{100 \mathrm{~ms}}(\mathrm{~ms})$

\section{Atrial Arrhythmias}

Inducibility (\%)

Burden (s)

Frequency (\#)
0

$0.8 \pm 1.5$

$1.3 \pm 2.3$
20

$23 \pm 50$

$3 \pm 5$

Data are mean $\pm S D$; asterisk $\left(^{*}\right)$ indicates $\mathrm{P}<0.05$ compared to WT. Subscript denotes PCL where appropriate. BCL, basic cycle length; PR $100 \mathrm{~ms}$, PR interval duration; $Q R S_{100 m s, ~}$ QRS duration; SNRT, sinus node recovery time; AVERP, AV nodal effective refractory period; $A E R P_{100 m s}$, atrial effective refractory period; VERP ${ }_{100 \mathrm{~ms}}$, ventricular effective refractory period. 
bioRxiv preprint doi: https://doi.org/10.1101/2021.05.20.444790; this version posted May 21, 2021. The copyright holder for this preprint (which was not certified by peer review) is the author/funder, who has granted bioRxiv a license to display the preprint in perpetuity. It is made available under aCC-BY-ND 4.0 International license.

FIGURES AND FIGURE LEGENDS: 

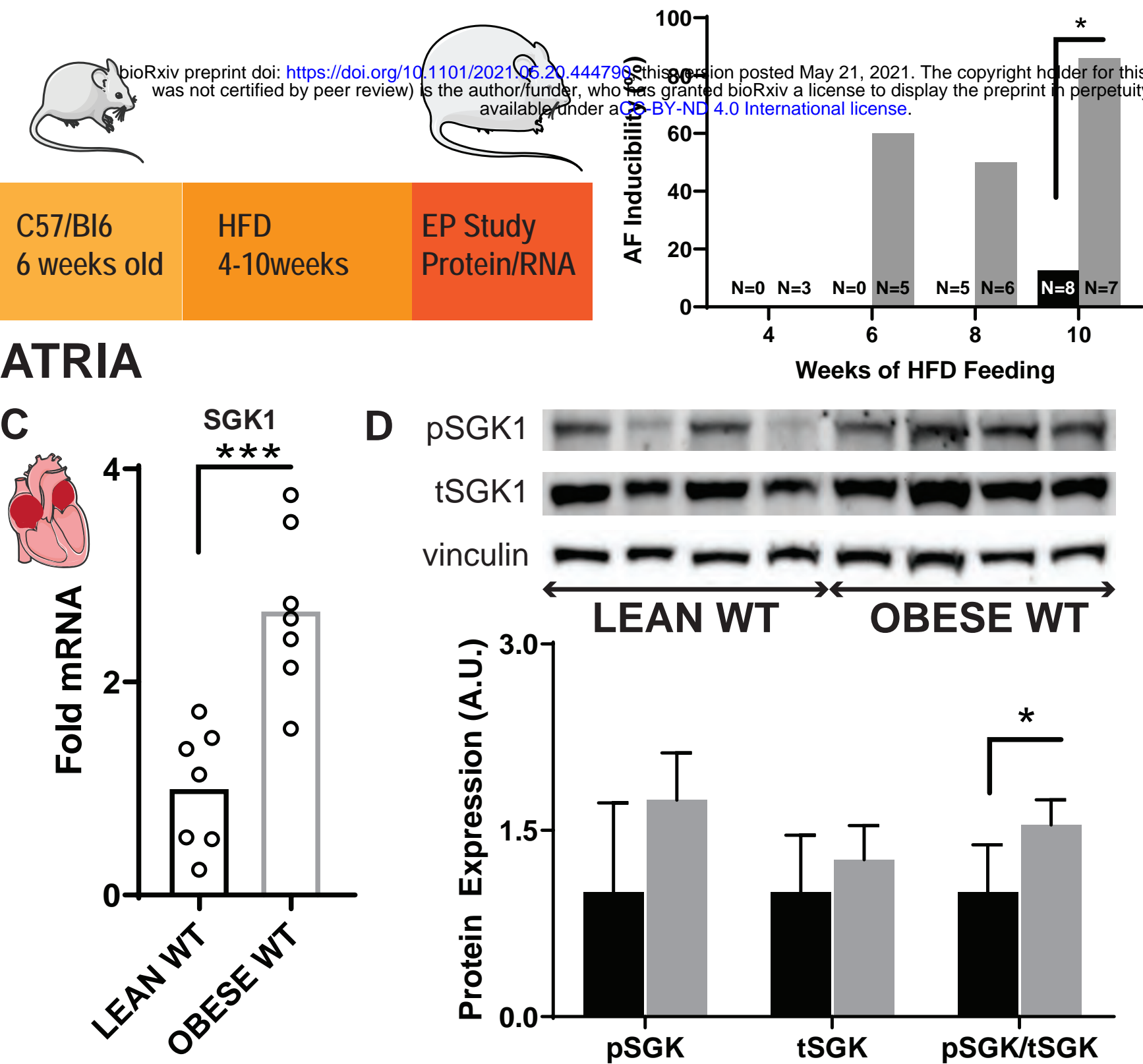

$\mathbf{V}$

VENTRICLES

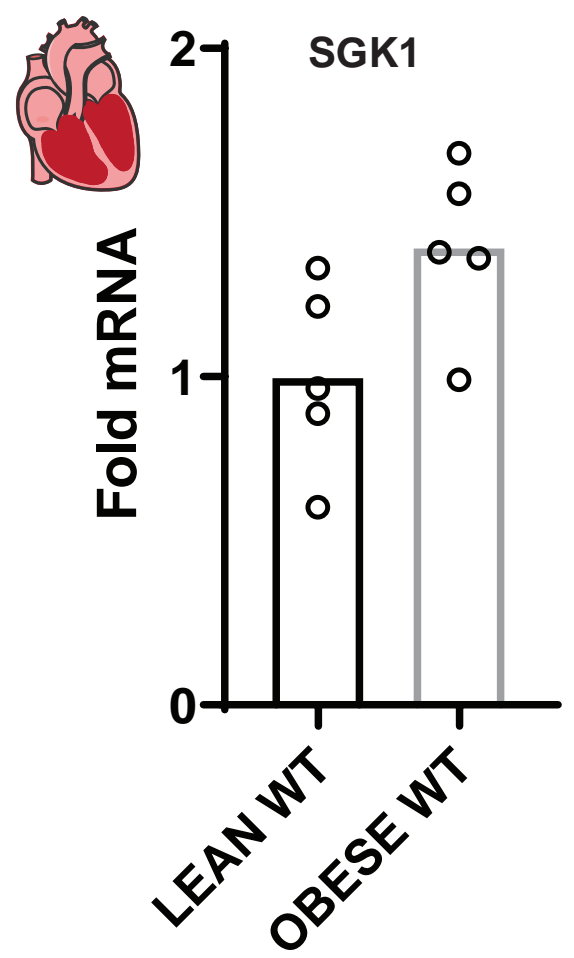

D pSGK1

tSGK1

vinculin
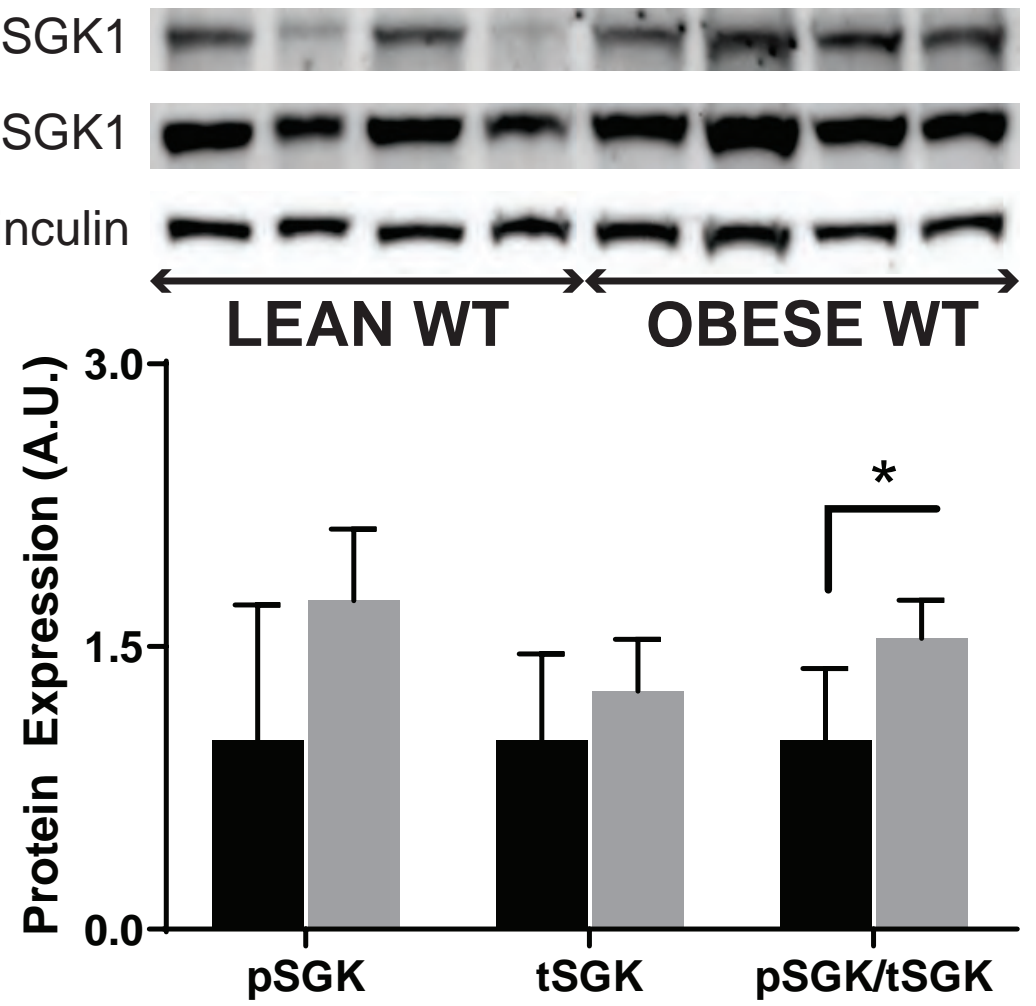

F pSGK1 '

tSGK1

vinculin

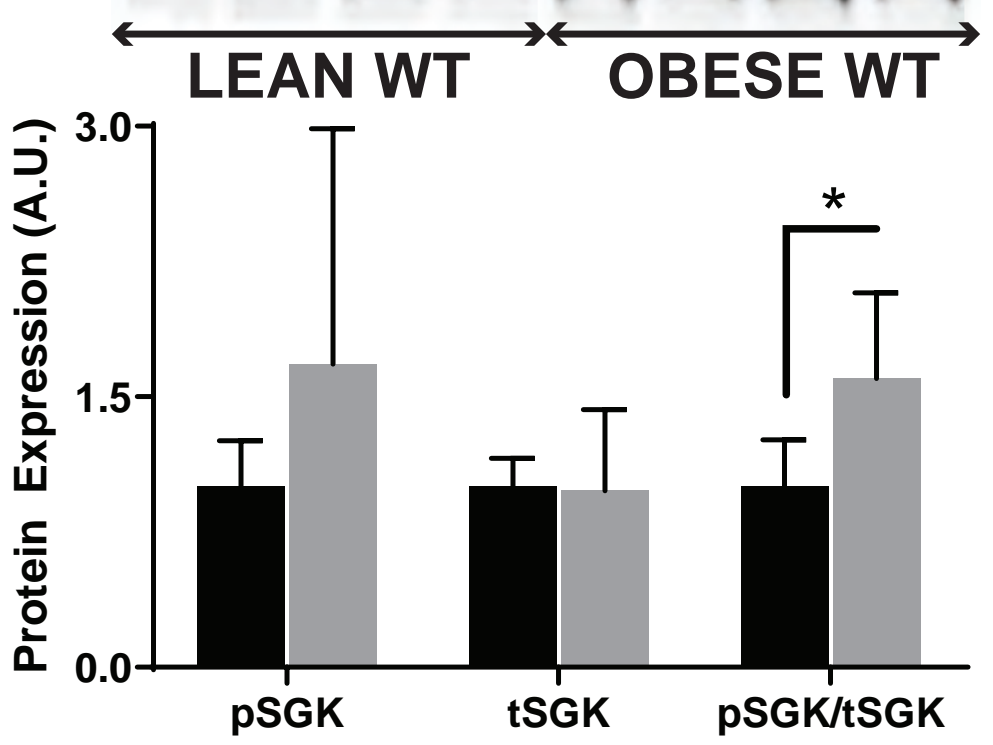


Figure 1: Diet induced obesity results in increased AF inducibility and is associated with upregulation of SGK1 signaling. $A$, Schema of mouse model using C57BL/6J mice. $B, A F$ inducibility in mice fed a HFD (black) or control diet (grey) for the specified period of time. $C$, Atrial SGK1 mRNA expression in obese versus lean mice. $D$, Expression of atrial phosphorylated (pSGK1) and total (tSGK1) SGK1 protein as quantified by Western blotting. E, Ventricular SGK1 mRNA expression in obese versus lean mice. $F$, Expression of ventricular phosphorylated (pSGK1) and total (tSGK1) SGK1 protein as quantified by Western blotting. 
bioRxiv preprint doi: https://doi.org/10.1101/2021.05.20.444790; this version posted May 21, 2021. The copyright holder for this preprint (which

was not certified by peer review) is the author/funder, who has granted bioRxiv a license to display the preprint in perpetuity. It is made available under aCC-BY-ND 4.0 International license.

Figure 2: SGK1 DN mice are protected from obesity-induced AF. $A, A F$ inducibility, by percent inducible, of lean and obese mice. $B$, Total summed duration of all AF episodes during each EP study. $C$, Number of episodes of induced $A F>250 \mathrm{~ms}$ in duration by mouse. $D$, Example intracardiac tracing showing pacing-induced $A F$. 

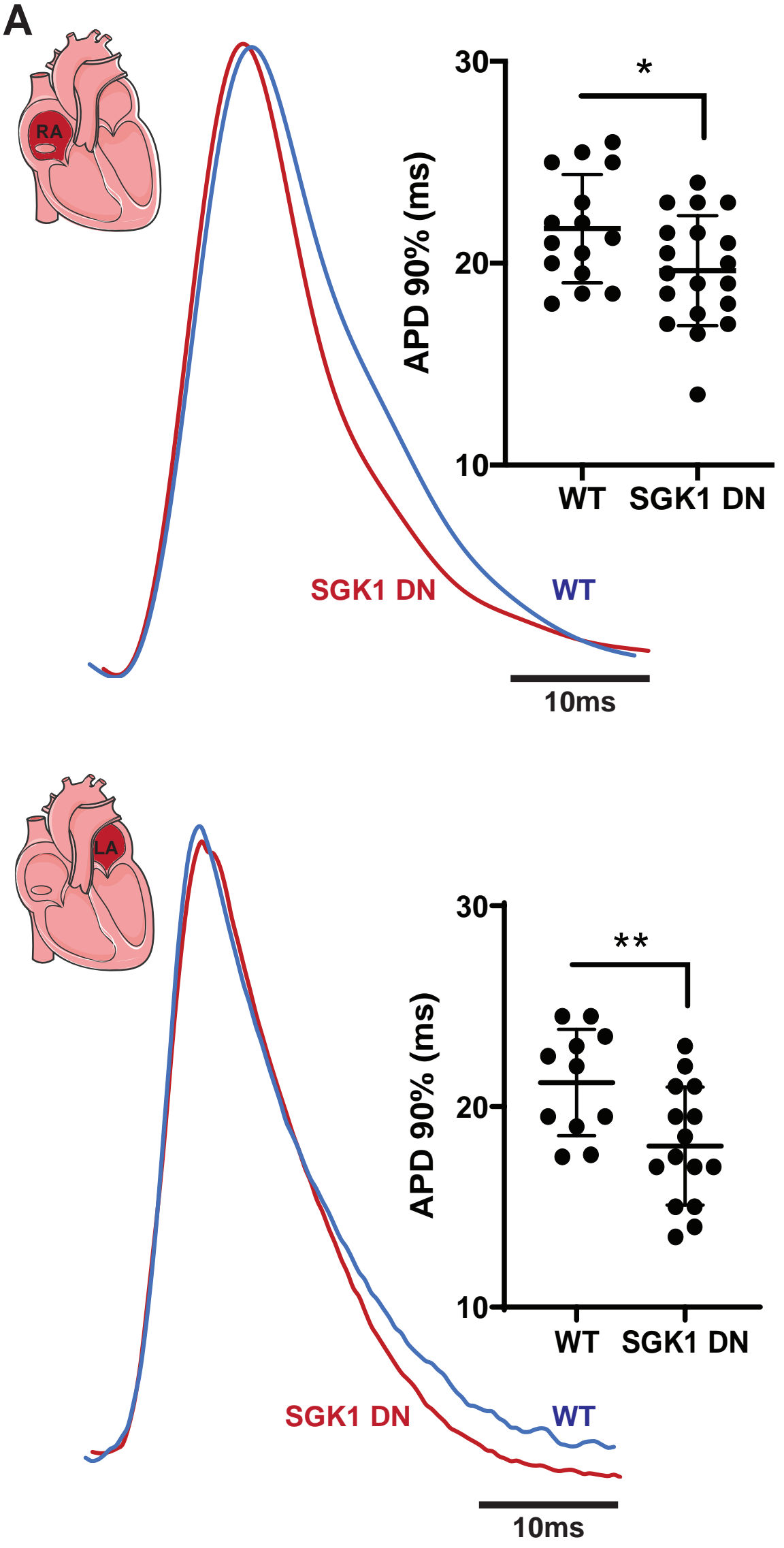

OBESE WT

OBESE SGK1 DN
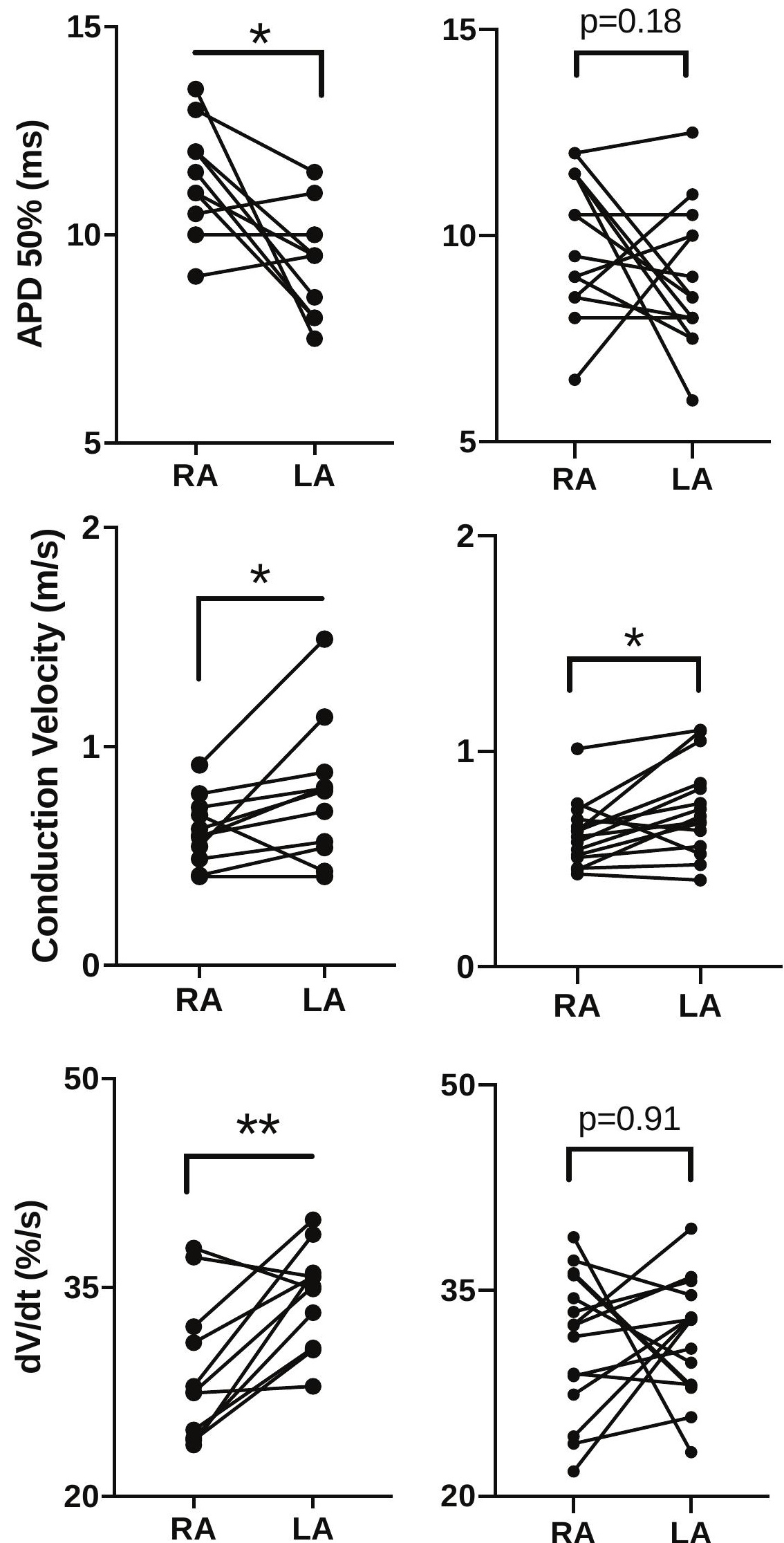
bioRxiv preprint doi: https://doi.org/10.1101/2021.05.20.444790; this version posted May 21, 2021. The copyright holder for this preprint (which

was not certified by peer review) is the author/funder, who has granted bioRxiv a license to display the preprint in perpetuity. It is made available under aCC-BY-ND 4.0 International license.

Figure 3: Atrial electrophysiologic effects of SGK1 genetic inhibition on obese mice. $A$, Right (top) and left (lower) atrial action potential durations at $90 \%$ repolarization in obese wild type and SGK1 DN mice. Tracings show representative optical action potential tracings. $B$, Interatrial differences in APD at 50\% repolarization (top), conduction velocity (middle), and upstroke velocity (dV/dt, bottom) in obese WT (left) and SGK1 DN (right) mouse atrial chambers. 
bioRxiv preprint doi: https://doi.org/10.1101/2021.05.20.444790; this version posted May 21, 2021. The copyright holder for this preprint (which

was not certified by peer review) is the author/funder, who has granted bioRxiv a license to display the preprint in perpetuity. It is made available under aCC-BY-ND 4.0 International license.

Figure 4: Effect of SGK1 genetic inhibition on $I_{N a}$ in obese left atrial cardiomyocytes. $A$, Example sodium current recordings from isolated left atrial (LA) cardiomyocytes. $B$, Currentvoltage relations in wild type (black) and SGK1 DN (red) isolated LA cardiomyocytes demonstrating a significant difference in peak $I_{N a}$. $C, I_{N a}$ activation-inactivation voltage dependences for WT (black) and SGK1 DN (red) left atrial cardiomyocytes demonstrating a depolarizing shift in the SGK1 DN myocytes. 


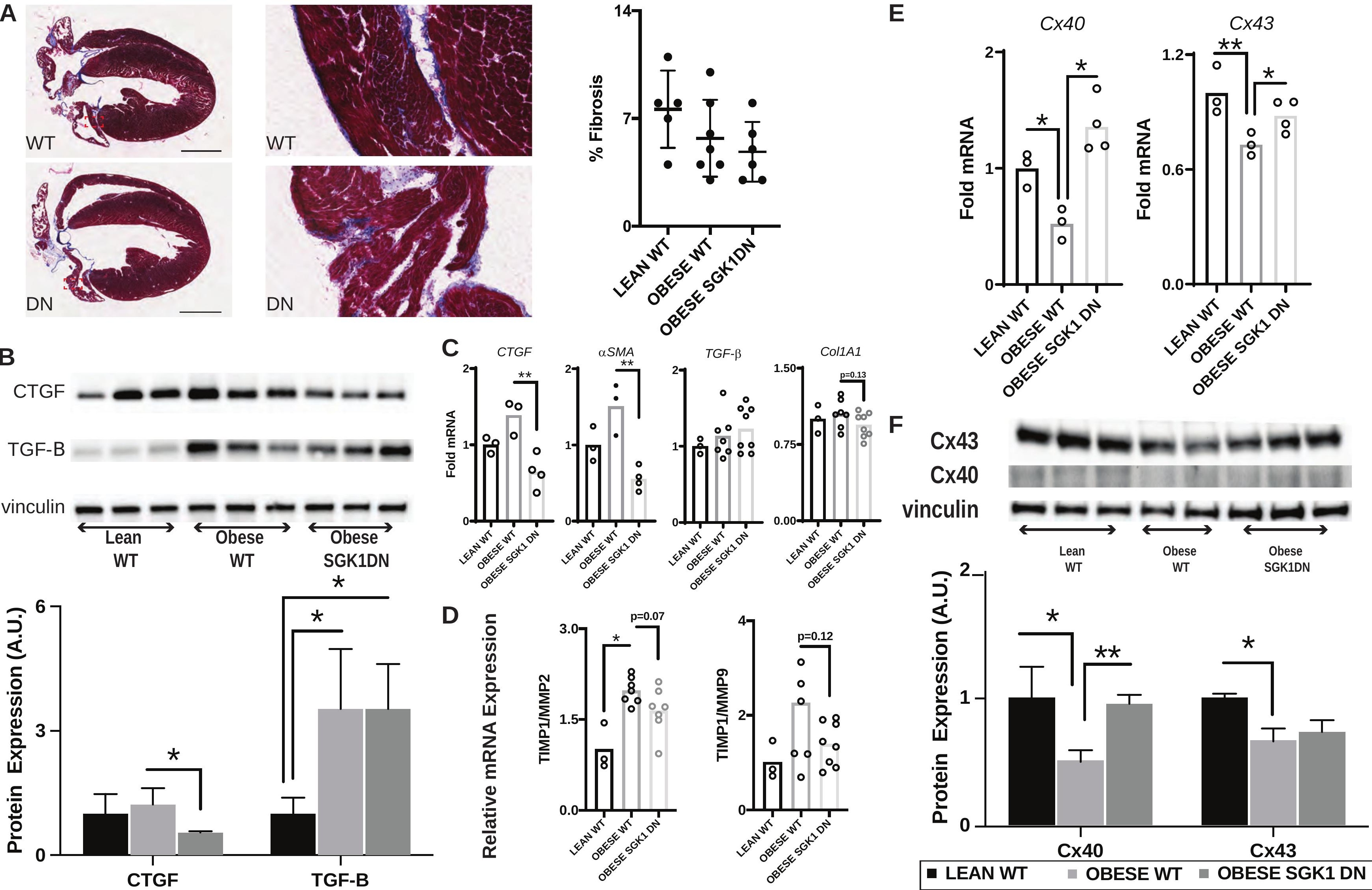


bioRxiv preprint doi: https://doi.org/10.1101/2021.05.20.444790; this version posted May 21, 2021. The copyright holder for this preprint (which

was not certified by peer review) is the author/funder, who has granted bioRxiv a license to display the preprint in perpetuity. It is made available under aCC-BY-ND 4.0 International license.

Figure 5: SGK1 genetic inhibition prevents obesity-induced atrial fibrotic signaling. $A$, Example Masson Trichrome stained tissue sections from mouse atria with quantification of fibrosis shown to the right. Images to the right are zoomed into the region delineated by the red dotted box. The scale bar $=2 \mathrm{~mm}$. $B$, Atrial CTGF and TGF- $\beta$ protein expression. $C$, Expression of fibrosis-related genes in lean and obese atria. $D$, Ratio of matrix metalloproteinase mRNA transcripts in atrial tissue. $E$, Expression of connexin mRNA transcripts. $F$, Connexin protein expression measured by Western Blot, with quantification below. 
$A$ 
bioRxiv preprint doi: https://doi.org/10.1101/2021.05.20.444790; this version posted May 21, 2021. The copyright holder for this preprint (which

was not certified by peer review) is the author/funder, who has granted bioRxiv a license to display the preprint in perpetuity. It is made available under aCC-BY-ND 4.0 International license.

Figure 6: SGK1 genetic inhibition prevents obesity-induced atrial inflammatory signaling. $A$, Atrial inflammatory gene transcript levels. $B$, Atrial macrophage content in lean and obese atria as measured by flow cytometry. $C$, Caspase 1 activity in obese atrial tissue as measured with a commercially available assay. $D$, Western blots of atrial NLRP3 and caspase subunits with quantification below. $E$, Western blots of atrial NFKB subunit $\mathrm{p} 65$ and its phosphorylated isoform with quantification below. 


\section{SUPPLEMENTAL TABLE:}

Supplemental Table 1: Primer sequences for genes of interest assayed by quantitative PCR

\begin{tabular}{|l|l|l|}
\hline Gene & Forward Sequence & Reverse Sequence \\
\hline Col1A1 & ATTCCCGTTCGAGTACGGAA & CTCGATCTCGTTGGATCCCT \\
\hline CTGF & CTGCAGACTGGAGAAGCAGA & GATGCACTTTTTGCCCTTCTT \\
\hline$a-S M A$ & GTCCCAGACATCAGGGAGTAA & TCGGATACTTCAGCGTCAGGA \\
\hline$T G F-B$ & GTCACTGGAGTTGTACGGCA & GGGCTGATCCCGTTGATTTC \\
\hline$C \times 40$ & GGTCCACAAGCACTCCACAG & CTGAATGGTATCGCACCGGAA \\
\hline$C \times 43$ & AGTTCCACCACTTTGGCGTG & GTGGAGTAGGCTTGGACCTT \\
\hline NLRP3 & TTTTCACAACTCGCCCAAGG & AAGCTAGAAGTGAGGCAGCA \\
\hline IL-1B & GGCTCATCTGGGATCCTCTC & TCATCTTTTGGGGTCCGTCA \\
\hline$B-a C t i n$ & GGCTGTATTCCCCTCCATCG & CCAGTTGGTAACAATGCCATGT \\
\hline$C C L 2$ & CAGCCAGATGCAGTTAACGC & GCCTACTCATTGGGATCATCTTG \\
\hline$C C L 5$ & CAGCAGCAAGTGCTCCAATC & CACACACTTGGCGGTTCCTT \\
\hline SGK1 & GGGTGCCAAGGATGACTTTA & CTCGGTAAACTCGGGATCGA \\
\hline$T I M P 1$ & CTATCCCTTGCAAACTGGAGA & ACCTGATCCGTCCACAAACA \\
\hline$M M P 2$ & CGGAGATCTGCAAACAGGACA & CGCCAAATAAACCGGTCCTT \\
\hline$M M P 9$ & GCGTGTCTGGAGATTCGACTT & TATCCACGCGAATGACGCT \\
\hline$C X C L 10$ & GACGGTCCGCTGCAACTG & CTTCCCTATGGCCCTCATTCT \\
\hline$C C L 6$ & GCTGGCCTCATACAAGAAATGG & GCTTAGGCACCTCTGAACTCTC \\
\hline VCAM1 & CCCAGGTGGAGGTCTACTCA & CAGGATTTTGGGAGCTGGTA \\
\hline
\end{tabular}


bioRxiv preprint doi: https://doi.org/10.1101/2021.05.20.444790; this version posted May 21, 2021. The copyright holder for this preprint (which was not certified by peer review) is the author/funder, who has granted bioRxiv a license to display the preprint in perpetuity. It is made available under aCC-BY-ND 4.0 International license.

SUPPLEMENTAL FIGURES: 


\section{HA Tag}

-

(1)
voria rype
WT DN

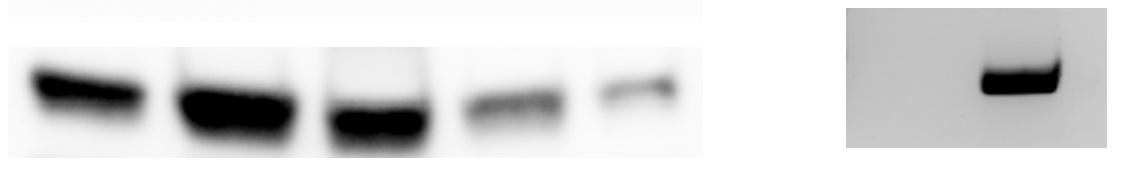

$A$

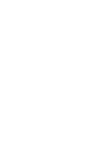

(

$-0 \quad B$
的口
SGK1 Dominant Negative

erata


bioRxiv preprint doi: https://doi.org/10.1101/2021.05.20.444790; this version posted May 21, 2021. The copyright holder for this preprint (which

was not certified by peer review) is the author/funder, who has granted bioRxiv a license to display the preprint in perpetuity. It is made available under aCC-BY-ND 4.0 International license.

Supplemental Figure 1: Cardiac specificity of SGK1 DN transgene. $A$, Western blots of hemagglutinin (HA) epitope tag present in only the atrial and ventricles of SGK1 DN mice, but not in non-cardiac tissues or in WT mice. $B$, Example DNA blot demonstrating presence of SGK1 transgene in SGK1 DN, but not WT, mice. 
bioRxiv preprint doi: https://doi.org/10.1101/2021.05.20.444790; this version posted May 21, 2021. The copyright holder for this preprint (which

was not certified by peer review) is the author/funder, who has granted bioRxiv a license to display the preprint in perpetuity. It is made available under aCC-BY-ND 4.0 International license.

Supplemental Figure 2: Phenotyping HFD-fed WT and SGK1 DN mice. $A$, Mouse body weight during HFD feeding. $B$, Heart weight and heart weight indexed to tibial length in mice. $C$, Blood pressure parameters measured after HFD feeding. $D$, Transthoracic echocardiography measured cardiac structural/functional parameters after HFD feeding. 


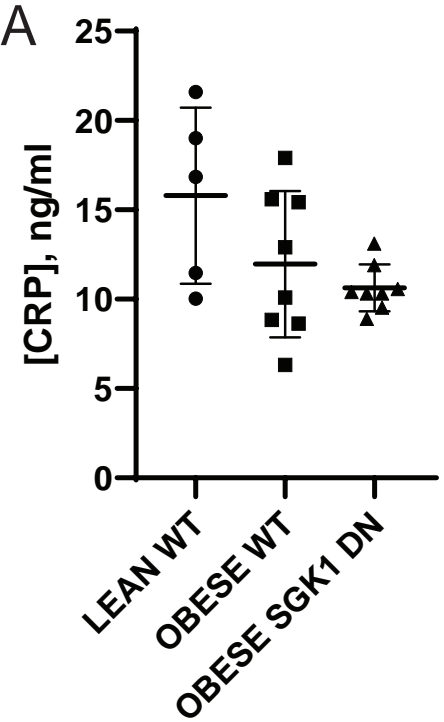

B ${ }^{600} 7$

है

$400-\quad$ a

$-200+1 / 2$

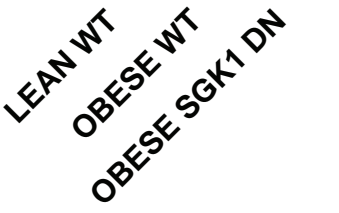


bioRxiv preprint doi: https://doi.org/10.1101/2021.05.20.444790; this version posted May 21, 2021. The copyright holder for this preprint (which

was not certified by peer review) is the author/funder, who has granted bioRxiv a license to display the preprint in perpetuity. It is made available under aCC-BY-ND 4.0 International license.

Supplemental Figure 3: Plasma markers of systemic inflammation. A, Plasma levels of Creactive protein (CRP). $B$, Plasma levels of interleukin 6 (IL-6). 